\title{
O Ecletismo nas Canções de Câmara para Canto e Piano de
}

\section{Carlos Alberto Pinto Fonseca}

\author{
Angelo José Fernandes, Raíssa Amaral Magrini, Sarah Victória Santibanez \\ Migliori, Heitor Basílio Coelho
}

Universidade Estadual de Campinas | Brasil

\begin{abstract}
Resumo: Este artigo aborda as 19 cançôes de câmara compostas por Carlos Alberto Pinto Fonseca para canto e piano. Trata-se de uma síntese de trabalhos realizados sobre a obra vocal deste compositor mineiro do século XX, ainda pouco mencionado na literatura sobre a música brasileira. Após uma breve exposição sobre o compositor e seu legado composicional, há uma discussão sobre o ecletismo contido em sua obra e, especialmente, no conjunto das 19 canções de câmara sob duas perspectivas: a histórica e a analítico-musical. Sob o ponto de vista histórico, as canções de câmara são apresentadas tendo como base as etapas da produção do compositor e os aspectos pessoais e estéticos que o influenciaram. $\mathrm{Na}$ sequência, o ecletismo é discutido com base nos elementos musicais e poéticos contidos nas canções: textos, tratamento dado ao piano, presença de vocalises e estéticas adotadas, a partir das quais são apresentadas características individuais de cada canção.
\end{abstract}

Palavras-chave: Carlos Alberto Pinto Fonseca, Canção de Câmara Brasileira, Nacionalismo, Impressionismo, Ecletismo composicional.

\begin{abstract}
The present paper presents the art songs composed by Carlos Alberto Pinto Fonseca for voice and piano. It is a synthesis of on the vocal works of this still neglected $20^{\text {th }}$ century Brazilian composer. After a brief presentation about the composer and his compositional legacy, there is a discussion about the eclecticism contained in the composer work and, especially, in the set of 19 art songs from two perspectives: the historical and the analytical-musical. From the historical point of view, the art songs are presented based on the various stages of the composer's production, in addition to the personal and aesthetic aspects that influenced him. In sequence, eclecticism is discussed based on the musical and poetic elements contained in the songs: texts, treatment given to the piano, presence of melodic vocalises and aesthetics adopted, from which individual characteristics of each song are presented.
\end{abstract}

Keywords: Carlos Alberto Pinto Fonseca, Brazilian Art Song, Brazilian Nationalism, Impressionism, Compositional Eclecticism. 


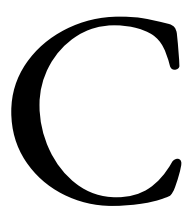
arlos Alberto Pinto Fonseca (1933-2006)1, regente e compositor mineiro de Belo Horizonte, é responsável pela criação de uma extensa e reconhecida obra vocal, em especial a porção destinada a coros, bastante executada por grupos no mundo inteiro. Embora de menor porte, mas tão significativo quanto, é o conjunto de suas cançôes de câmara compostas para voz e piano. De um total de quase 200 peças compostas ${ }^{2}, 19$ são destinadas a essa formação e revelam um compositor eclético em suas escolhas estilísticas e poéticas, conhecedor das possibilidades da voz humana e habilidoso na escrita pianística, fato que se justifica por ter sido o piano o instrumento por meio do qual construiu sua base musical.

Segundo Matheus (2010, p. 31), CAPF compôs principalmente para piano solo, violão, canto e piano, coro infantil e coro adulto. Há, ainda, obras para várias outras formações, em especial grupos de câmara. A autora observa que, apesar de se tratar de uma obra diversificada, $74 \%$ das peças foram compostas ou arranjadas para coro (adulto e infantil) e 9,7\% para canto e piano, o que confirma a hegemonia da voz no legado do compositor.

Essas proporções explicam-se pelo fato de que por praticamente 40 anos de sua vida, CAPF atuou como regente do Ars Nova - Coral da UFMG, historicamente, o grupo coral brasileiro mais premiado nacional e internacionalmente, tendo sido considerado pelo compositor Almeida Prado (1943-2010) como o “maior conjunto vocal do Brasil”. Segundo Santos (2001, p. 22), este coro foi a principal atividade profissional de CAPF permitiu-lhe, em diversas oportunidades, exercer seus talentos de regente e compositor. O autor observa que, "contando com um conjunto de vozes sempre preparado tecnicamente, este compositor pôde expandir seu processo criativo, utilizando toda a capacidade de empreendimento e realização técnico-musical deste corpo coral” (SANTOS, 2001, p. 22), e afirma que "essa ininterrupta atividade junto a este corpo coral proporcionou ao compositor oportunidades singulares de criação e experimentação na escrita musical destinada a obras vocais”

\footnotetext{
${ }^{1}$ Doravante, usaremos a sigla CAPF para referência ao nome do compositor Carlos Alberto Pinto Fonseca. Ressaltamos que essa sigla com as iniciais do nome do maestro era utilizada por ele próprio ao assinar algumas de suas composiçóes e, desde o primeiro trabalho de pesquisa realizado sobre sua atividade como compositor e regente, pesquisadores que, de alguma forma, conviveram com ele a têm usado frequentemente.

${ }^{2}$ Em seu trabalho realizado sobre a vida e a obra de CAPF, Santos (2001) elaborou um catálogo das obras do compositor no qual estão registradas 169 peças. Matheus (2010), durante a realização de seu mestrado que tratava dos elementos impressionistas na obra de CAPF, encontrou 26 partituras de obras não catalogadas por Santos (2001), somando um total de 195 obras. Além dessas, por meio de nossas pesquisas sobre o compositor, temos encontrado ainda outras peças não mencionadas em nenhum dos citados trabalhos. Por tal razão, podemos afirmar que o número é superior a 200 peças.
} 
FERNANDES, Angelo José; MAGRINI, Raíssa Amaral; MIGLIORI, Sarah Victória Santibanez; COELHO, Heitor Basílio. O Ecletismo nas Canções de Câmara para Canto e Piano de Carlos Alberto Pinto Fonseca. Revista Vórtex, Curitiba, v.8, n.2, p. 1-30, 2020.

(SANTOS, 2001, p. 30). De fato, grande parte da produção coral de CAPF foi criada especificamente para as possibilidades desse coro e, da mesma forma, as partes solistas de suas obras corais, bem como suas cançốes de câmara, foram compostas para cantores específicos com quem ele se relacionava.

O trabalho que segue trata, pois, dos citados $9,7 \%$ da obra de CAPF para canto e piano, sendo fruto de ampla investigação que está sendo realizada pelo grupo de pesquisa Canto: arte, técnica e pedagogia do Instituto de Artes da UNICAMP que, desde 2012, dedica-se ao estudo de toda a obra vocal do compositor por meio do projeto Estilo e interpretação na obra vocal de Carlos Alberto Pinto Fonseca. O grupo, que inclui cantores, pianistas e regentes corais, tem entre seus principais objetivos o trabalho de edição crítica das partituras, na sua maioria manuscritos do próprio compositor, e seu estudo analítico sob a ótica do intérprete. Além de passar pelo processo de edição e análise, grande parte desse repertório é realizado em recitais e concertos. As partituras das canções mencionadas neste trabalho foram editadas e disponibilizadas por Magrini (2017, p. 133-197) a partir dos manuscritos cedidos a estes autores pelo Instituto Cultural Carlos Alberto Pinto Fonseca ICAPF, que atualmente administra todo o arquivo particular do compositor.

\section{O ecletismo nas canções de CAPF sob uma perspectiva histórica}

\subsection{CAPF e o ecletismo}

Apesar de considerado por muitos como um compositor nacionalista, CAPF sempre se dizia um compositor eclético que, apesar de ter escrito muita música de inspiração nacionalista, compôs peças impressionistas e até mesmo dodecafônicas.

O aspecto nacionalista na prática composicional de CAPF é sempre ressaltado por estar presente nas várias fases de sua atividade criativa. Além disso, pode ser percebido por meio de duas características presentes especialmente em sua obra coral: sua relação com a música popular e folclórica e, principalmente, a forte influência que as religiôes afro-brasileiras exerceram sobre o compositor. Entre os anos de 1956 e 1960, CAPF viveu na Bahia, onde teve contato com essa cultura que o influenciou de forma significativa, levando-a a compor inúmeras peças baseadas não somente nos textos dessas religióes, mas, principalmente na força rítmica dos tambores. Sua mais importante 
FERNANDES, Angelo José; MAGRINI, Raíssa Amaral; MIGLIORI, Sarah Victória Santibanez; COELHO, Heitor Basílio. O Ecletismo nas Canções de Câmara para Canto e Piano de Carlos Alberto Pinto Fonseca. Revista Vórtex, Curitiba, v.8, n.2, p. 1-30, 2020.

obra expressa significativamente esse aspecto nacionalista: a Missa Afro-Brasileira (de Batuque e Acalanto), composta em 1971 para coro misto a capella e solistas. Segundo Fernandes (2005, p. 61),

Premiada em 1976 pela Associação Paulista de Críticos da Arte como "Melhor obra vocal do ano", a missa reúne temas do folclore nacional, intercalando trechos que retratam a força primitiva dos ritmos africanos, com trechos que ressaltam a ternura e a simplicidade do acalanto, além de explorar outras formas populares (FERNANDES, 2005, p. 61).

Para Matheus (2010, p. 53), a estética nacionalista permeia toda a produção composicional de CAPF. Segundo a autora, "sua sensibilidade ao nacional pode ser vista na temática das peças, no uso de escalas modais, nos arranjos de música popular, na utilização do folclore em criaçóes e arranjos e também na presença de elementos afro-brasileiros” (MATHEUS, 2010, p. 53).

Apesar da força do nacionalismo na obra do compositor, um estudo mais aprofundado de suas criaçôes nos permite afirmar que CAPF é, antes de tudo, um compositor eclético, assim como ele próprio afirmou várias vezes. Para Matheus (2010, p. 51), tal ecletismo se faz notar pelo uso de diferentes correntes estéticas, pela utilização dos idiomas tonal, atonal e modal e, ainda, pelo emprego de técnicas composicionais como o dodecafonismo e o contraponto.

As diferentes técnicas e estéticas coexistiam dentro de um mesmo período de tempo. Assim, em um mesmo ano, Carlos Alberto Pinto Fonseca compunha peças completamente diferentes. [...] Presente em toda sua trajetória composicional desde as primeiras obras, esse ecletismo tem um caráter peculiar por não acontecer em fases cíclicas de negação e valorização de determinada estética. [...] Pode ser admitida a possibilidade de, ao longo dos anos, o compositor ter mudado sua percepção sobre o seu ecletismo, mas o mesmo continuou sendo um traço estético até o final de sua vida. Em 2006, no ano de seu falecimento, Carlos Alberto Pinto Fonseca nos disse de forma enfática, que ele era um compositor eclético e não nacionalista. (MATHEUS, 2010, p. 51-53)

De forma muito especial, o conjunto de suas 19 canções para canto e piano são um excelente exemplo dessa variedade estilística e poética. Neste conjunto, há desde cançốes simples com caráter seresteiro ou de acalanto típicas do Nacionalismo, até cançóes que utilizam o atonalismo e técnicas estendidas, passando por outras que apresentam elementos impressionistas, sofisticada elaboração harmônica e uma escrita pianística mais complexa. Há também cançôes que exaltam a cultura afrobrasileira e apresentam maior complexidade rítmica. Importante ressaltar também que a escolha dos textos das canções demonstra o ecletismo mencionado. O compositor utilizou textos de sua própria 
FERNANDES, Angelo José; MAGRINI, Raíssa Amaral; MIGLIORI, Sarah Victória Santibanez; COELHO, Heitor Basílio. O Ecletismo nas Canções de Câmara para Canto e Piano de Carlos Alberto Pinto Fonseca. Revista Vórtex, Curitiba, v.8, n.2, p. 1-30, 2020.

autoria, textos provenientes da liturgia católica e da Umbanda, poesias de Rabindranth Tagore (18611941) traduzidas por Plácido Barbosa (1871-1938), de Carlos Drummond de Andrade (1902-1987), de Manuel Bandeira (1886-1968), de Carmen de Melo (s.d.) e de Robert Jones (s.d.) e, ainda, poemas chineses traduzidos por Paulo Mendes Campos (1922-1991).

\subsection{As 19 canções de câmara}

As 19 canções foram compostas entre 1952 e 1999. Na verdade, considerando as datas de composição que conseguimos levantar, podemos afirmar que não há uma regularidade nessa produção. Provavelmente, em função de inspiraçôes, tendências estilísticas de momento e outros fatores externos como interferências emocionais ou influências religiosas, CAPF concebeu suas canções em pequenos períodos espaçados ao longo de sua vida. Segundo Matheus (2010, p. 30), mesmo tendo deixado um número considerável de composiçôes, a atitude criativa do compositor não ocorria de forma sistemática. "Sujeito a interferências afetivo-emocionais em sua esfera pessoal, Fonseca [em entrevista ao maestro Sérgio Magnani ${ }^{3}$ ] deixou transparecer o peso de alguns problemas vividos por ele sobre sua atividade composicional” (MATHEUS, 2010, p. 31).

A composição das canções se deu em quatro momentos principais: entre 1952 e 1955 foram criadas suas cinco primeiras cançóes; no ano de 1977, três; em 1987 e 1988, outras três; por fim, em 1999, foi composta mais uma, provavelmente a última. Infelizmente, não temos a informação sobre o ano de composição das outras sete canções.

A seguir, apresentamos uma tabela por nós elaborada com a relação de todas as cançôes, seus respectivos anos de composição, a fonte do texto (poeta ou proveniência), a quem elas foram dedicadas e a classificação vocal adequada segundo nossa análise, considerando a partitura original sem transposições.

\footnotetext{
${ }^{3}$ FONSECA, Carlos Alberto Pinto. Belo Horizonte: 1983. Entrevista concedida a Sérgio Magnani para o Departamento de Pesquisa e Extensão da Fundação Clóvis Salgado. Musicoteca/áudio, arquivo 69 A e B.
} 
FERNANDES, Angelo José; MAGRINI, Raíssa Amaral; MIGLIORI, Sarah Victória Santibanez; COELHO, Heitor Basílio. O Ecletismo nas Canções de Câmara para Canto e Piano de Carlos Alberto Pinto Fonseca. Revista Vórtex, Curitiba, v.8, n.2, p. 1-30, 2020.

TABELA 1 - Relação das 19 canções para canto e piano de CAPF com as informações: ano de composição, título da obra, origem do texto, dedicatória e classificação vocal adequada.

\begin{tabular}{|c|c|c|c|c|}
\hline Ano & Título da canção & Autor ou origem do texto & Dedicatória & $\begin{array}{c}\text { Classificação vocal } \\
\text { adequada }\end{array}$ \\
\hline 1952 & Escuta Moreno & CAPF & Maria Lúcia Godoy & Mezzo-soprano \\
\hline 1952 & Berceuse & CAPF & Maria Lúcia Godoy & Mezzo-soprano \\
\hline 1953 & Canção da Retirante & CAPF & Lia Salgado & Soprano \\
\hline 1954 & Volta & Rabindranath Tagore & $\begin{array}{l}\text { Carmen Pinto } \\
\text { Fonseca }\end{array}$ & Mezzo-soprano \\
\hline 1955 & Poema do Gitanjali no 84 & Rabindranath Tagore & Sem dedicatória & Soprano ou Tenor \\
\hline 1977 & A Estrela & Manuel Bandeira & Sem dedicatória & Soprano ou Tenor \\
\hline 1977 & Ogum de Nagô & Umbanda & Sem dedicatória & Soprano ou Tenor \\
\hline 1977 & Oxalá & Umbanda & $\begin{array}{c}\text { Francisco Campos } \\
\text { Neto }\end{array}$ & Baixo-barítono \\
\hline 1987 & Ave Maria & Oração católica & Katya Kazzaz & Soprano \\
\hline 1988 & As sem-razões do amor & $\begin{array}{c}\text { Carlos Drummond de } \\
\text { Andrade }\end{array}$ & Katya Kazzaz & Soprano \\
\hline 1988 & O Tempo perdido & Rabindranath Tagore & Katya Kazzaz & Soprano \\
\hline 1999 & Ave Maria & Oração católica & Sem dedicatória & Soprano \\
\hline s.d. & Água do coração & Carmen de Mello & Rita Paixão & Soprano ou Tenor \\
\hline s.d. & Fumaça & $\begin{array}{l}\text { Poema chinês traduzido por } \\
\text { Paulo Mendes Campos }\end{array}$ & Sem dedicatória & Baixo-barítono \\
\hline s.d. & Desespero em luz & $\begin{array}{l}\text { Poema chinês traduzido por } \\
\text { Paulo Mendes Campos }\end{array}$ & Sem dedicatória & Baixo-barítono \\
\hline s.d. & Ao espelbo & $\begin{array}{l}\text { Poema chinês traduzido por } \\
\text { Paulo Mendes Campos }\end{array}$ & Sem dedicatória & Baixo-barítono \\
\hline s.d. & OMoinho & $\begin{array}{l}\text { Poema chinês traduzido por } \\
\text { Paulo Mendes Campos }\end{array}$ & Sem dedicatória & Baixo-barítono \\
\hline s.d. & Meu nome & $\begin{array}{l}\text { Poema chinês traduzido por } \\
\text { Paulo Mendes Campos }\end{array}$ & Sem dedicatória & Baixo-barítono \\
\hline s.d. & What if I speed & Robert Jones & Sem dedicatória & $\begin{array}{c}\text { Mezzo-Soprano ou } \\
\text { Barítono }\end{array}$ \\
\hline
\end{tabular}

Fonte: Elaborado pelos autores deste trabalho com base em SANTOS (2001) e MATHEUS (2010). 
FERNANDES, Angelo José; MAGRINI, Raíssa Amaral; MIGLIORI, Sarah Victória Santibanez; COELHO, Heitor Basílio. O Ecletismo nas Canções de Câmara para Canto e Piano de Carlos Alberto Pinto Fonseca. Revista Vórtex, Curitiba, v.8, n.2, p. 1-30, 2020.

Da relação apresentada, tivemos acesso às partituras de 18 canções, faltando-nos apenas What if I speed, única canção em língua inglesa, com texto de Robert Jones, provavelmente adequada a vozes médias (mezzo-soprano ou barítono) por exigir uma extensão vocal de Dó\#3 a Mi44, conforme informado no catálogo de obras elaborado por Santos (2001, p. 65).

\subsection{Classificaçóes vocais adequadas}

Embora CAPF não tenha indicado em todas as canções para qual classificação vocal ele as compôs, seis delas foram claramente concebidas para a voz de barítono ou baixo-barítono por estarem escritas na clave de fá. A análise da tessitura ${ }^{5}$ utilizada pelo compositor nos leva a acreditar que tais canções são mais adequadas para a voz de baixo-barítono do que para a voz de barítono. Oxalá de 1977, embora dedicada a um barítono - Francisco Campos Neto (1947) - exige do cantor a extensão de um baixo-barítono, com a presença de notas graves como Mi1, Fá1 e Sol1. Da mesma forma, as Cinco cançôes sobre poemas chineses traduzidos por Paulo Mendes Campos - Fumaça (s.d.), Desespero em luz (s.d.), Ao espelho (s.d.), O Moinho (s.d.) e Meu nome (s.d.) - também possuem tessitura e extensão vocal adequadas a um baixo-barítono.

Aparentemente, criadas para vozes agudas em função da extensão vocal exigida, Escuta Moreno (1952), Berceuse (1952) e Volta (1954) possuem uma tessitura mais grave que a de um soprano. Além disso, apresentam certas peculiaridades que nos permitem acreditar que são mais adequadas à voz de mezzo-soprano. Berceuse é a única entre todas que apresenta a indicação para qual tipo de voz foi composta, no caso mezzo-soprano, tendo sido escrita em 1952 e dedicada à cantora Maria Lúcia Godoy (1924), importante soprano brasileira que, naquela época, era classificada como mezzo-soprano e realizava repertórios para esta classificação vocal. Também dedicada a essa cantora, Escuta Moreno foi composta no mesmo ano, mas "anterior a Berceuse", indicação colocada por CAPF no fim da partitura. A indicação e a dedicatória à mesma cantora fazem-nos acreditar em uma espécie de "parentesco" entre as duas canções, além do fato de que ambas foram escritas para a voz de mezzo-

\footnotetext{
${ }^{4}$ No âmbito deste trabalho, utilizamos o sistema francês que define o dó central do piano como Dó3.

${ }^{5}$ É importante apontar que, no âmbito da música vocal, as palavras extensão e tessitura possuem significados distintos. Segundo Miller "tessitura no canto é um termo que define a região mais confortável da voz, diferente de extensão, que define toda a região que o cantor consegue atingir, desde a nota mais grave até a mais aguda” (MILLER, 2019, p. 243).
} 
FERNANDES, Angelo José; MAGRINI, Raíssa Amaral; MIGLIORI, Sarah Victória Santibanez; COELHO, Heitor Basílio. O Ecletismo nas Canções de Câmara para Canto e Piano de Carlos Alberto Pinto Fonseca. Revista Vórtex, Curitiba, v.8, n.2, p. 1-30, 2020.

soprano. Volta, por sua vez, é a que possui tessitura mais grave, tendo sido dedicada à mãe de CAPF, Carmen Pinto Fonseca, e estreada pela mezzo-soprano belo-horizontina Vânia Soares (1946), para quem o compositor escreveu a canção.

Por fim, as nove canções restantes, que constituem o maior grupo, são adequadas às vozes agudas: Canção da Retirante (1953), Poema do Gitanjali no 84 (1955), A Estrela (1977), Ogum de Nagô (1977), Ave Maria (1987), As sem-razóes do amor (1988), O Tempo perdido (1988), Ave Maria (1999) e Água do coração (s.d.). Embora adequadas às vozes agudas, é importante considerar que cinco delas foram dedicadas e compostas para cantoras específicas, sendo que todas eram sopranos: Lia Salgado, Katya Kazzaz e Rita Paixão.

\subsection{Tendências composicionais e inspirações}

Anteriormente, apontamos os quatro principais momentos em que CAPF dedicou-se à composição de cançóes para canto e piano. Mencionamos, ainda, o fato de que sua atitude criativa estava sujeita a inspirações de diferentes ordens. Olhando para a linha do tempo dessas canções, observamos certas tendências que se revelam, sendo a primeira delas seu desejo em homenagear a cantora Maria Lúcia Godoy para quem escreveu suas duas primeiras canções em 1952: Escuta Moreno e Berceuse. Importante salientar que, em 1952, CAPF ainda era um jovem compositor de 19 anos de idade em busca de inspirações para suas composições. Maria Lúcia Godoy já, à época, era uma cantora reconhecida em Belo Horizonte, assim como a soprano Lia Salgado (1914-1980), a quem o compositor homenageou dedicando a Canção da Retirante no ano seguinte (1953). Segundo Calais e Chantal (2020, p. 305), ao dedicar essa canção ao soprano, é possível supor que "o compositor conhecia os predicados vocais da artista, que detinha destaque como solista em óperas e também como recitalista, reconhecida, inclusive, como intérprete of icial do compositor Camargo Guarnieri (19071993)" (CALAIS; CHANTAL, 2020, p. 305).

Berceuse, Canção da Retirante e Volta, compostas respectivamente em 1952, 1953 e 1954, possuem a mesma temática poética que é a relação entre mãe e filho. A primeira é uma canção de ninar com texto de autoria do próprio compositor. A segunda, também com texto de CAPF, aborda uma situação dramática de uma mãe nordestina tentando fazer dormir seu filho que tem fome, 
FERNANDES, Angelo José; MAGRINI, Raíssa Amaral; MIGLIORI, Sarah Victória Santibanez; COELHO, Heitor Basílio. O Ecletismo nas Canções de Câmara para Canto e Piano de Carlos Alberto Pinto Fonseca. Revista Vórtex, Curitiba, v.8, n.2, p. 1-30, 2020.

caracterizando-se também como uma berceuse. A terceira, dedicada à sua mãe, "aborda a morte precoce de um filho e o pedido de sua mãe implorando para que ele volte para vê-la” (MATHEUS, 2010, p.38).

Se Escuta Moreno, Berceuse e Canção da Retirante são melodias acompanhadas musicalmente por uma escrita mais simples ao piano, Volta, apesar de manter a temática poética das duas anteriores, foi escrita sobre um poema traduzido de R. Tagore e mostra uma nova fase do compositor do ponto de vista musical, apresentando elementos impressionistas e uma escrita pianística mais elaborada que dialoga constantemente com a linha do canto, por meio de elementos musicais que se relacionam com o texto. Poema do Gitanjali no 84, composta um ano depois (1955), junta-se a Volta nessas mesmas características, confirmando um novo momento de CAPF, uma vez que ele utiliza outro poema de R. Tagore, trabalha com diversos elementos impressionistas e trata a função pianística com maior elaboração. A sofisticação do tratamento dado ao piano nessas cançôes de 1954 e 1955 retornará com O Tempo perdido, composta em 1988. Nesta última, CAPF também utiliza um poema de R. Tagore, além de elementos impressionistas. É importante mencionar que os anos em que Volta e Poema do Gitanjali no 84 foram compostas são exatamente os anos em que CAPF começou a estudar com o mestre alemão H. J. Koellreutter (1915-2005) nos Seminários de Música da Pró-Arte, em São Paulo.

No ano de 1977, o compositor escreveu três cançôes, sendo duas delas - Ogum de Nagô e Oxalá - peças que trazem a forte influência da cultura afro-brasileira sobre sua obra. Essa influência esteve presente desde o período em que se mudou para a Bahia (1956-1960), mas, na década de 1970, ela se apresenta ainda mais significativa, principalmente em sua obra coral. No conjunto das cançóes, apenas essas duas trazem essa temática e, assim como muitas de suas peças afro-brasileiras para coro, têm seus textos retirados do livro 400 Pontos Riscados e Cantados na Umbanda e Candomblé.

Passados dez anos, CAPF compôs mais três canções entre os anos 1987 e 1988, sendo as três dedicadas a Katya Kazzaz, cantora do Ars Nova - Coral da UFMG: Ave Maria, Assem-razóes do amor e O Tempo perdido. A ligação entre essas canções é apenas a cantora homenageada pelo compositor.

\footnotetext{
${ }^{6}$ Este livro esteve muito presente na produção afro-brasileira de CAPF, sendo sempre citado pelos estudiosos de sua música. Segundo Santos (2001, p. 29), apesar da forte influência da cultura afro-brasileira sobre o maestro, ele "declarou jamais ter ido a algum terreiro de candomblé" e, em entrevista concedida ao musicólogo, falou de seu interesse por tal cultura: "Meu interesse em escrever música de inspiração afro-brasileira surgiu depois de ouvir um conjunto chamado Cantores do Céu, com uma sonoridade fascinante, incluindo vozes graves. Depois de ouvir este conjunto, ganhei um livro contendo 400 pontos riscados, cantados e dançados de umbanda. Comecei a partir dos textos deste livro a criar melodias por conta" (SANTOS, 2001, p. 30).
} 
FERNANDES, Angelo José; MAGRINI, Raíssa Amaral; MIGLIORI, Sarah Victória Santibanez; COELHO, Heitor Basílio. O Ecletismo nas Canções de Câmara para Canto e Piano de Carlos Alberto Pinto Fonseca. Revista Vórtex, Curitiba, v.8, n.2, p. 1-30, 2020.

Não há uma conexão musical ou poética entre elas. A primeira é uma oração de origem católica; a segunda, escrita sobre um poema de Carlos Drummond de Andrade, apresenta características mais nacionalistas como a rítmica e o caráter seresteiro; e a terceira, escrita sobre um poema de R. Tagore, apresenta elementos musicais típicos do Impressionismo.

Em 1999, CAPF compôs sua segunda Ave Maria. Naquela época, o compositor regia um coro infantil chamado Pequenos Cantores da Serra da Cepep. Da mesma forma que o Ars Nova - Coral da UFMG inspirou várias de suas peças para coro adulto, os Pequenos Cantores da Serra foram uma de suas inspirações na criação de peças originais e arranjos para coro infantil. Segundo Magrini (2017, p. 106), pelas informaçóes contidas no manuscrito do compositor, a Ave Maria foi inicialmente composta para esse grupo. Contudo, no próprio manuscrito, a autora observou que CAPF riscou a dedicatória e a indicação de que se tratava de uma obra para coro infantil e designou a canção para soprano ou tenor.

Neste contexto em que observamos as tendências e inspirações na produção de canções de CAPF dentro de uma perspectiva histórica, não podemos afirmar muito sobre as Cinco canções que foram escritas sobre poemas chineses traduzidos por Paulo Mendes Campos. Trata-se de cinco peças muito curtas, compostas para serem executadas sequencialmente e que apresentam uma linguagem experimental com a presença de politonalismo, utilização de clusters e, também, técnicas estendidas ${ }^{7}$, ainda que de forma modesta. Contudo, é curioso o fato de que não há um manuscrito concluído dessas cançôes, mas apenas rascunhos em um bloco no qual se encontram outros rascunhos de obras compostas para barítono, flauta e piano, coincidentemente, com textos de poemas chineses traduzidos também por Paulo Mendes Campos: Nuvens de cisnes brancos (1970), Gelado e Mudo Amor. Embora não possamos afirmar, acreditamos em que todas essas peças são de um mesmo período, provavelmente o princípio da década de 1970, quando CAPF trabalhou com vários poemas com a temática oriental. Do ano de 1970, por fim, há ainda um quarteto para flauta, clarinete, contralto e piano, sob poema de Li Tai Po, traduzido por CAPF: Adeus às margens de um rio. Segundo Matheus (2010, p. 48), o trio Nuvens de Cisnes Brancos e o quarteto Adeus às margens de um rio,

\footnotetext{
7 Técnicas estendidas ou expandidas são um conjunto de procedimentos técnicos não tradicionais que, na maioria das vezes, criam sonoridades não comuns. No caso do canto, são técnicas estendidas: Sprechstimme, recitações com ou sem alturas definidas, vocabulários sônicos não textuais, risadas, gargalhadas, sussurros, gritos, falsete, trêmolo muting, vocal muting, glissando, clicks, clucks, assobios, entre outros.
} 
FERNANDES, Angelo José; MAGRINI, Raíssa Amaral; MIGLIORI, Sarah Victória Santibanez; COELHO, Heitor Basílio. O Ecletismo nas Canções de Câmara para Canto e Piano de Carlos Alberto Pinto Fonseca. Revista Vórtex, Curitiba, v.8, n.2, p. 1-30, 2020.

ambas de 1970, são tipicamente impressionistas. Nos outros dois trios, sobre os quais não é possível precisar a data de composição, o compositor utilizou a técnica do dodecafonismo.

\section{O ecletismo nas canções de CAPF sob uma perspectiva analítico-musical}

Voltando à questão do ecletismo presente no conjunto das canções, apontamos, a seguir, aspectos que ilustram a diversidade de escolhas do compositor entre elas: os textos, a escrita pianística, a utilização de vocalises, bem como características musicais (material melódico, rítmico e harmônico) que separam as cançóes em grupos de diferentes correntes estéticas.

\subsection{A escolha dos textos}

Predominantemente, os textos utilizados pelo compositor estão escritos em português, com exceção da Ave Maria de 1999 composta em latim, e What if I speed, na língua inglesa.

Há canções em que foram utilizados textos de linguagem mais simples como aqueles da própria autoria de CAPF, usados em suas três primeiras cançóes que tratam de situaçóes cotidianas, ainda que possuam certa carga dramática como a Canção da Retirante que, embora seja uma canção de ninar, trata da infelicidade das pessoas que passaram pelo abandono da seca.

O compositor revelou certo apreço por textos mais modernos, cheios de metáforas e simbolismos, ausência de rimas e pontuações, além de fragmentações do verso poético como é o caso dos poemas chineses traduzidos por Paulo Mendes Campos e os poemas simbolistas de R. Tagore: Volta, Poema do Gitanjali no 84 e $O$ Tempo perdido. Importante ressaltar a utilização de textos simbolistas justamente nas canções impressionistas, prática comum na composição de mélodies francesas impressionistas.

Não menos envolvidos de subjetividade e símbolos, são os poemas típicos do Modernismo Brasileiro como A Estrela de Manuel Bandeira, As sem-razóes do amor de Carlos Drummond de Andrade e Água do coração de Carmen de Melo. Especialmente os dois primeiros, trata-se de textos utilizados por muitos compositores brasileiros na criação de cançôes de câmara.

Os simbolismos também estão presentes nas canções ritualísticas Oxalá e Ogum de Nagô, cujos 
FERNANDES, Angelo José; MAGRINI, Raíssa Amaral; MIGLIORI, Sarah Victória Santibanez; COELHO, Heitor Basílio. O Ecletismo nas Canções de Câmara para Canto e Piano de Carlos Alberto Pinto Fonseca. Revista Vórtex, Curitiba, v.8, n.2, p. 1-30, 2020.

textos são provenientes do livro 400 pontos riscados e cantados na Umbanda e Candomblé.

Por fim, afirmando sua religiosidade, CAPF utilizou, em duas de suas cançóes, o texto da oração católica Ave Maria, uma em português e a outra em latim. Enfatizamos sua predileção por esse texto católico tradicionalmente utilizado por muitos autores em diversas composições para voz solista e/ou coro desde os primórdios do período renascentista. Além das duas cançóes sacras para canto e piano, CAPF compôs pelo menos outras cinco Ave Marias para coro.

\subsection{A escrita para piano}

Outro aspecto importante a ser apontado é a escrita para o piano. Muitas das cançôes são tipicamente melodias acompanhadas. Contudo, mesmo nessas canções de melodia acompanhada, o tratamento dado ao piano é diverso. Por exemplo, em Berceuse, Canção da Retirante, bem como nas duas Ave Marias, o acompanhamento é simples, regular e normalmente baseado em um motivo de acompanhamento. Já em Escuta Moreno, sua primeira canção, CAPF varia o tipo de acompanhamento nas várias estrofes do texto, utilizando desde texturas cordais, quase corais, até acordes arpejados de forma ágil imitando uma harpa, conforme exemplificado na Figura 1, a seguir:

FIGURA 1 - Excerto de Escuta Moreno (c. 13-14), em que o piano realiza um acompanhamento de acordes arpejados.

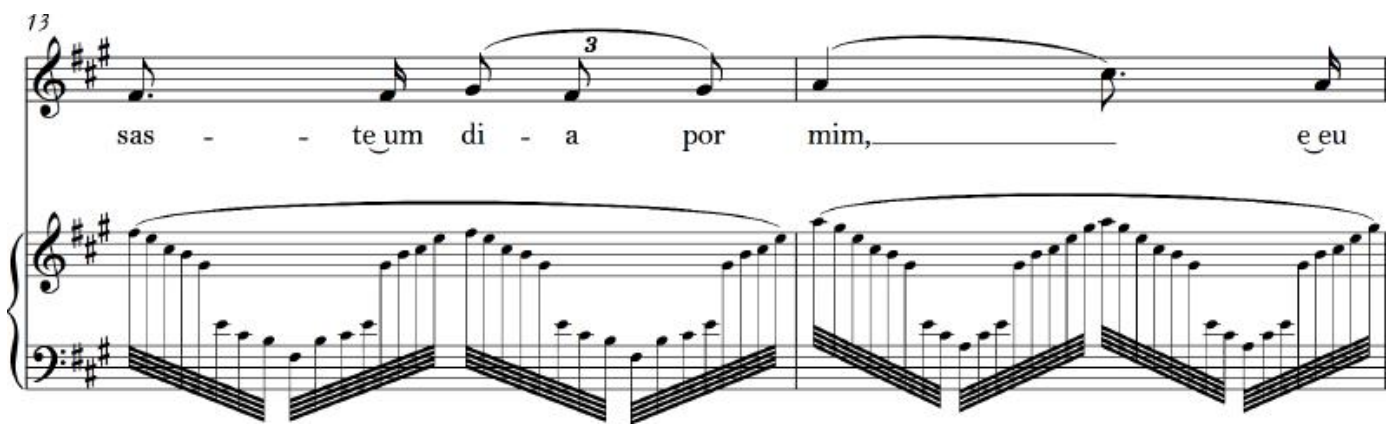

Fonte: MAGRINI (2017, p. 139).

A Estrela mantém certa regularidade no acompanhamento, contudo, sua escrita mostra uma melodia acompanhada por um contraponto no qual a distribuição das vozes sugere uma escrita coral, apresentando certa independência da linha melódica e movimentando-se predominantemente de forma paralela, como ilustrado na Figura 2, a seguir: 
FIGURA 2 - Melodia acompanhada por vozes que se movimentam paralelamente em A Estrela (c. 03-06).

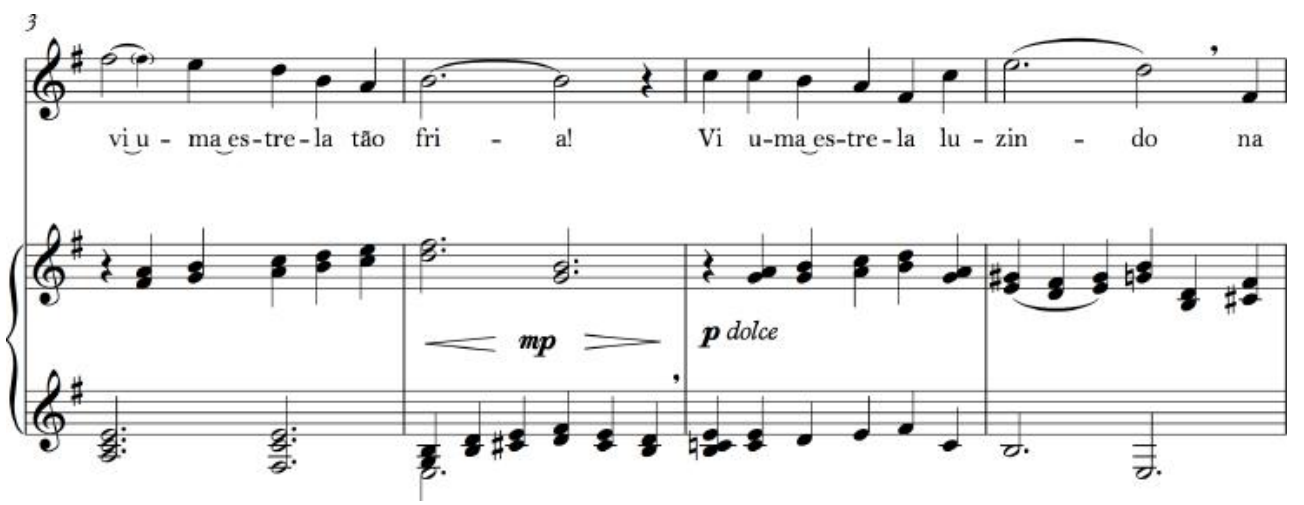

Fonte: MAGRINI (2017, p. 160).

Assem-razóes do amor apresenta um acompanhamento mais sincopado e rítmico, característico do nacionalismo presente na canção brasileira desde a modinha e o lundu e que reforça seu caráter mais seresteiro. Na linha do piano, a parte da mão direita realiza, constantemente, acordes com ritmo similar ao da melodia apresentada no canto. Nas notas mais agudas desses acordes, há uma outra melodia que se comporta como uma segunda voz, devendo ser tocada com as mesmas intençóes prosódicas do texto cantado. A Figura 3, a seguir, ilustra essa situação:

FIGURA 3 - Primeiros compassos de As sem-razóes do amor (c. 01-04) que resumem o tratamento dado ao piano: ritmos característicos nacionalistas e a presença de uma "segunda voz" nas notas mais agudas da mão direita.

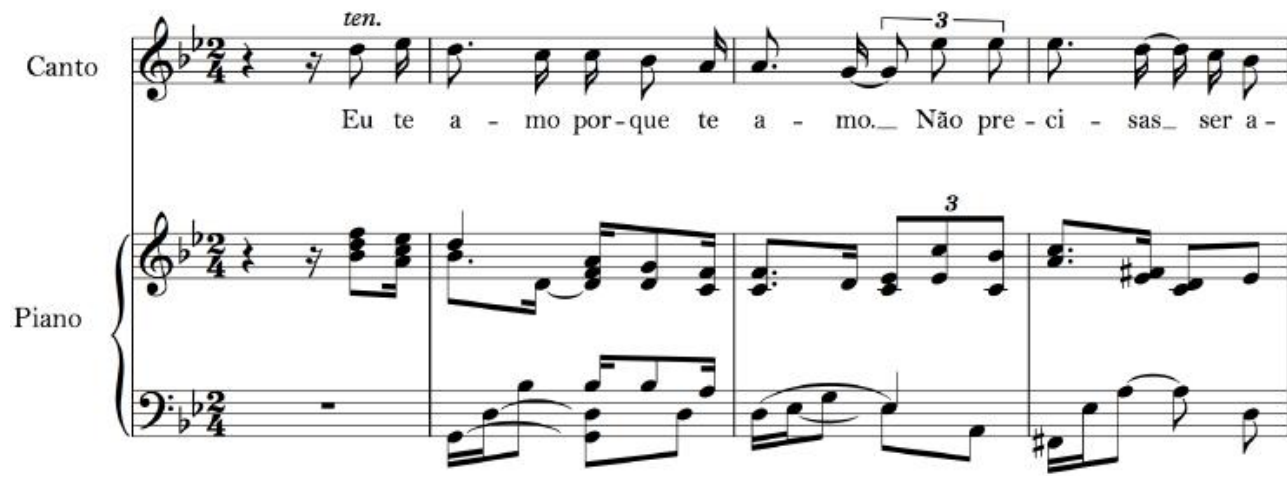

Fonte: MAGRINI (2017, p. 184).

O aspecto rítmico e nacionalista também está presente em Ogum de Nagô e Oxalá, contudo, de forma bastante diversa. Nessas duas canções de inspiração afro-brasileira, o piano assume uma função mais percussiva, imitando tambores, sem expor suas características melódicas. Em grande 
parte dessas canções, essa função percussiva se mantém. Na Figura 4, a seguir, há um exemplo da escrita rítmica da linha do piano. Importante ressaltar que tais ritmos poderiam ter sido escritos sem a utilização de pausas e, ainda assim, o piano soaria de forma percussiva. Essas pausas recorrentes, contudo, sugerem um toque mais próximo das práticas da percussão popular, como se as pausas abafassem o couro.

FIGURA 4 - Excerto de Ogum de Nagô, c. 01-04, que exemplifica a utilização do piano de forma percussiva sugerindo o som de tambores.

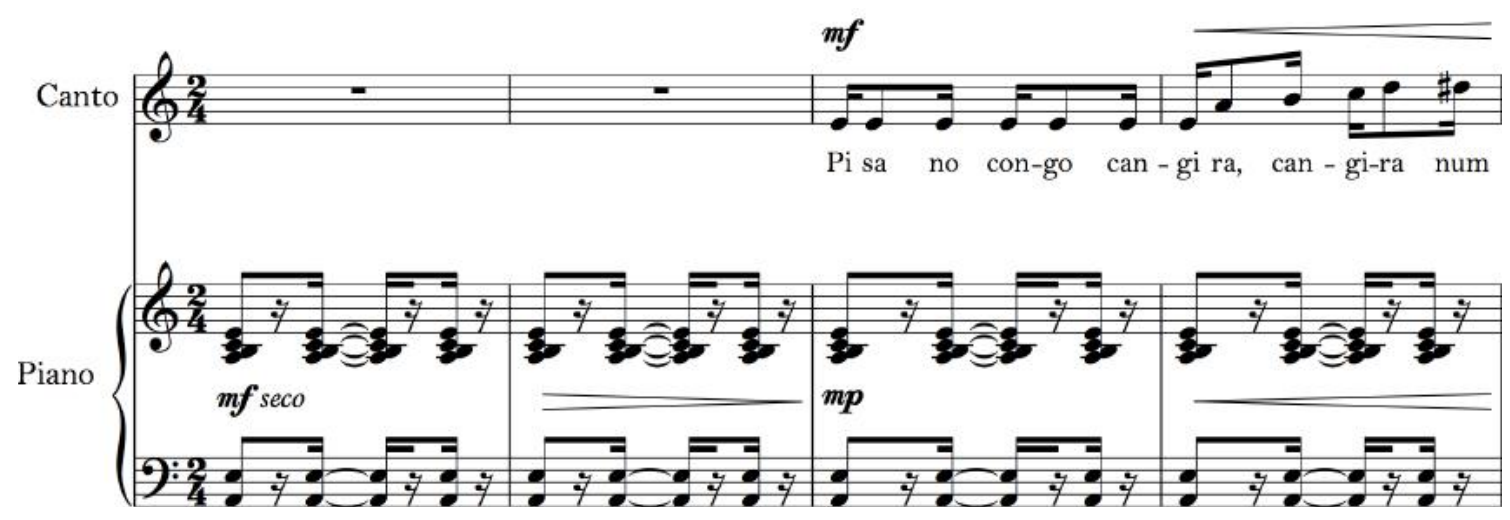

Fonte: MAGRINI (2017, p. 168).

Tanto em Ogum de Nagô quanto em Oxalá, há, além da predominância da escrita percussiva, trechos em estilo recitativo para a linha do canto com acompanhamento do piano, realizando acordes de longa duração. Em Oxalá, nos trechos em recitativo, o piano ainda dialoga com a linha vocal quase de forma responsorial, acompanhando os recitativos e respondendo-os como atabaques de um ritual de Umbanda. Em peças com textos provindos das religióes afro-brasileiras, sejam canções de câmara, sejam obras para coro, é comum o hibridismo entre o ritmo afro e o recitativo barroco europeu. $\mathrm{Na}$ Figura 5, a seguir, há um pequeno trecho de recitativo de Oxalá, no qual se pode observar: as duas funçóes do piano (a de acompanhar a linha do cantor e a de dialogar com o texto respondendo-o de forma percussiva); o movimento melódico descendente, forma como o compositor tratou o binômio texto-música na palavra "desceu”; e, ainda, o intervalo melódico de quarta justa descendente da linha do canto que remete à retórica do recitativo barroco, neste caso, dentro de um ritual afro-brasileiro. 
FERNANDES, Angelo José; MAGRINI, Raíssa Amaral; MIGLIORI, Sarah Victória Santibanez; COELHO, Heitor Basílio. O Ecletismo nas Canções de Câmara para Canto e Piano de Carlos Alberto Pinto Fonseca. Revista Vórtex, Curitiba, v.8, n.2, p. 1-30, 2020.

FIGURA 5 - Excerto de Oxalá, c. 32-33, que exemplifica: o hibridismo entre o afro e o barroco; os papéis do piano de acompanhar o recitativo com acordes de longa duração e de dialogar com o texto respondendo de forma percussiva; e o movimento melódico descendente como tratamento musical dado ao texto que diz "desceu para nos salvar".

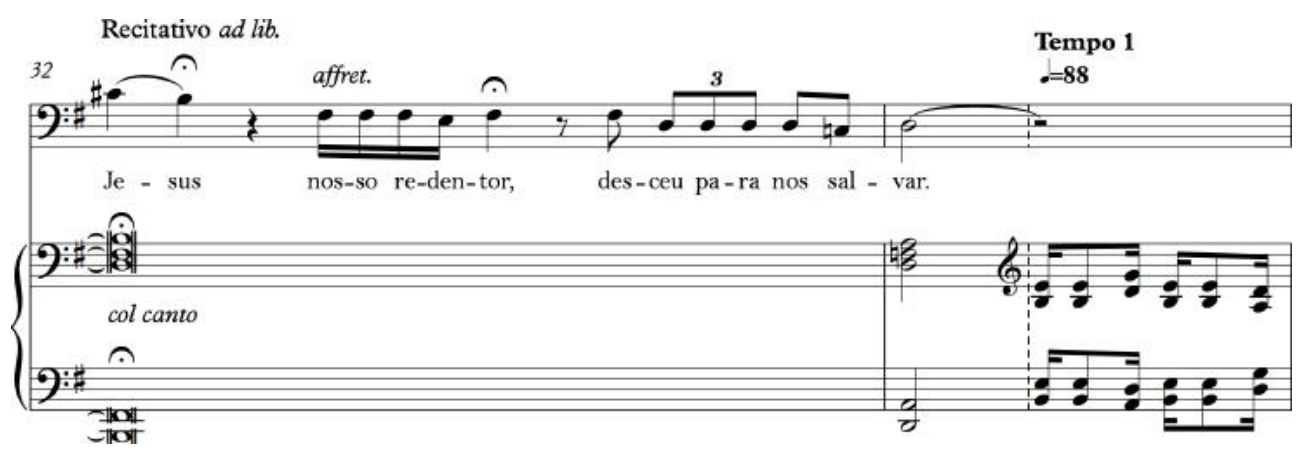

Fonte: MAGRINI (2017, p. 177).

Essa exploração timbrística do piano também acontece de outras formas nas cançôes que apresentam elementos impressionistas. Em Poema do Gitanjali no 84, por exemplo, há vários exemplos. Segundo Magrini (2017, p. 50), no c. 22, os arpejos do piano "sugerem uma relação da escrita musical com o texto, evocando o som da lira”, por meio de acordes de apenas três ou quatro sons, o que remete ao reduzido número de cordas do instrumento. Além disso, nos c. 23 a 25, um trêmulo de fusas e a inserção de escalas cromáticas em fusas dialogam com o texto. "Os trêmulos sugerem os sussurros das folhas e a escala cromática sugere a chuva” (MAGRINI, 2017, p. 50-51). A Figura 6, a seguir, ilustra como o compositor utiliza meios texturais e timbrísticos do piano para evocar elementos do texto em Poema do Gitanjali no 84:

FIGURA 6 - Trecho de Poema do Gitanjali no 84, c. 22-25, em que a linha do piano, por meio de diferentes explorações texturais e timbrísticas, relaciona-se com os elementos do texto: o som da lira, os sussurros das folhas e a chuva.

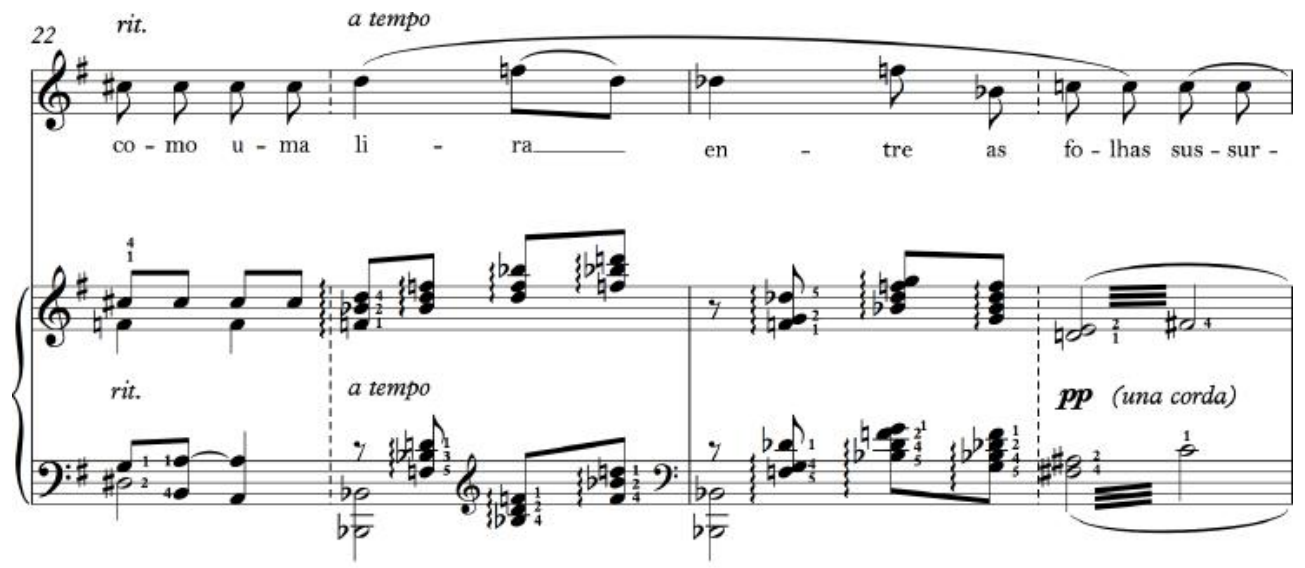


FERNANDES, Angelo José; MAGRINI, Raíssa Amaral; MIGLIORI, Sarah Victória Santibanez; COELHO, Heitor Basílio. 0 Ecletismo nas Canções de Câmara para Canto e Piano de Carlos Alberto Pinto Fonseca. Revista Vórtex, Curitiba, v.8, n.2, p. 1-30, 2020.

FIGURA 6 (cont.) - Trecho de Poema do Gitanjali no 84, c. 22-25, em que a linha do piano, por meio de diferentes exploraçôes texturais e timbrísticas, relaciona-se com os elementos do texto: o som da lira, os sussurros das folhas e a chuva.

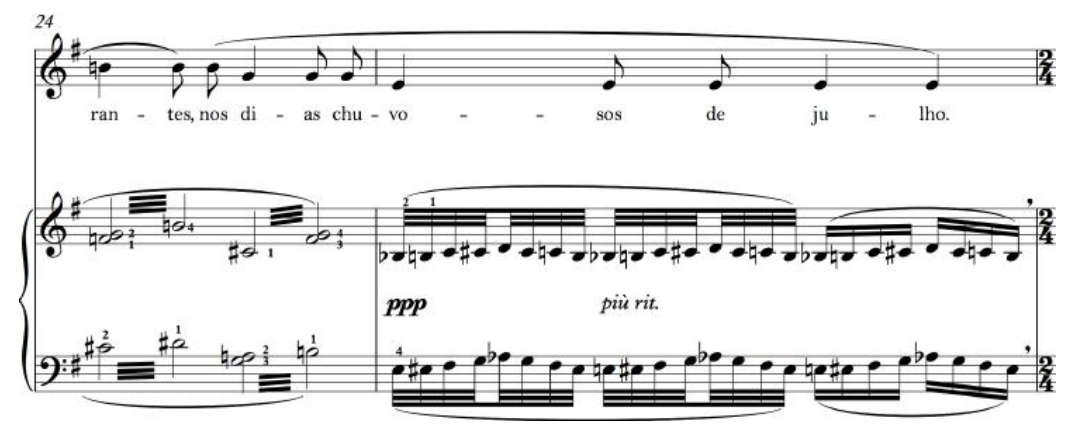

Fonte: MAGRINI (2017, p. 157).

Na canção $O$ Tempo perdido, por sua vez, há, entre outras, uma indicação ao pianista que nos chama a atenção. Trata-se de uma marcação por meio da qual o compositor sugere um "toque impressionístico” como o “mecanismo do relógio”. Para Magrini (2017, p. 101), esse apontamento faz alusão ao texto "cada momento da minha vida". Entendemos ainda que, como o termo mecanismo do relógio significa toda a complexa parte mecânica responsável pelo funcionamento do relógio, ou ainda, no âmbito da relojoaria, é entendido como o movimento do relógio, essa indicação é uma recomendação para um toque preciso e articulado. A Figura 7, a seguir, ilustra mais esse elemento timbrístico-evocativo utilizado por CAPF. É importante notar que tal indicação tem uma duração de apenas dois compassos (c. 16-17), uma vez que, no fim do c. 17, há uma recomendação de cedendo, seguida no c. 18 por uma indicação de calmo. Essas anotações sugerem certa flexibilidade temporal.

FIGURA 7 - Trecho de $O$ Tempo perdido. No c. 16, há uma mudança de andamento. Neste ponto, o compositor indica para o piano que utilize um "Toque impressionístico" como o "mecanismo do relógio".

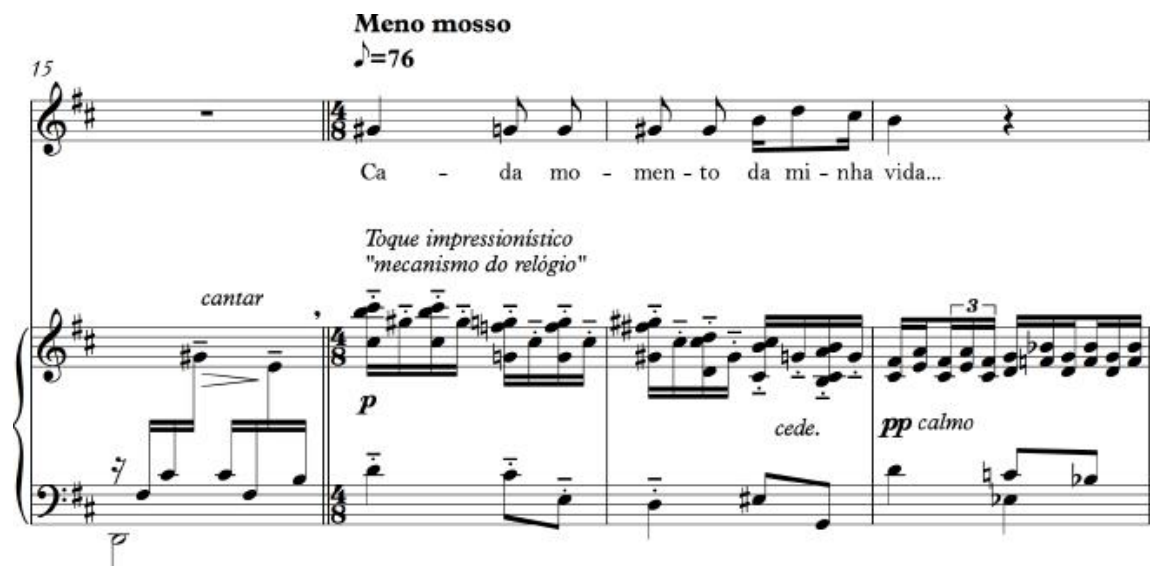

Fonte: MAGRINI (2017, p. 165). 


\subsection{A utilização de vocalises}

A presença de vocalises em determinadas seções ou frases de uma peça é um traço bastante característico de CAPF, presente nas canções de câmara e também muito explorado em suas obras corais. Tal peculiaridade não é um elemento que justifica o ecletismo, mas a forma como o compositor a explora nas canções é diversa e digna de nota. As canções que apresentam vocalises são Berceuse, $A$ Estrela, As sem-razóes do amor e Água do coração. Na primeira, há um vocalize em /a/; nas duas seguintes em bocca chiusa; e, na última, em /o/, conforme exemplificado na Figura 8, a seguir:

FIGURA 8 - Exemplo de utilização de vocalize na linha vocal neste excerto de Água do Coração (c. 13-19).

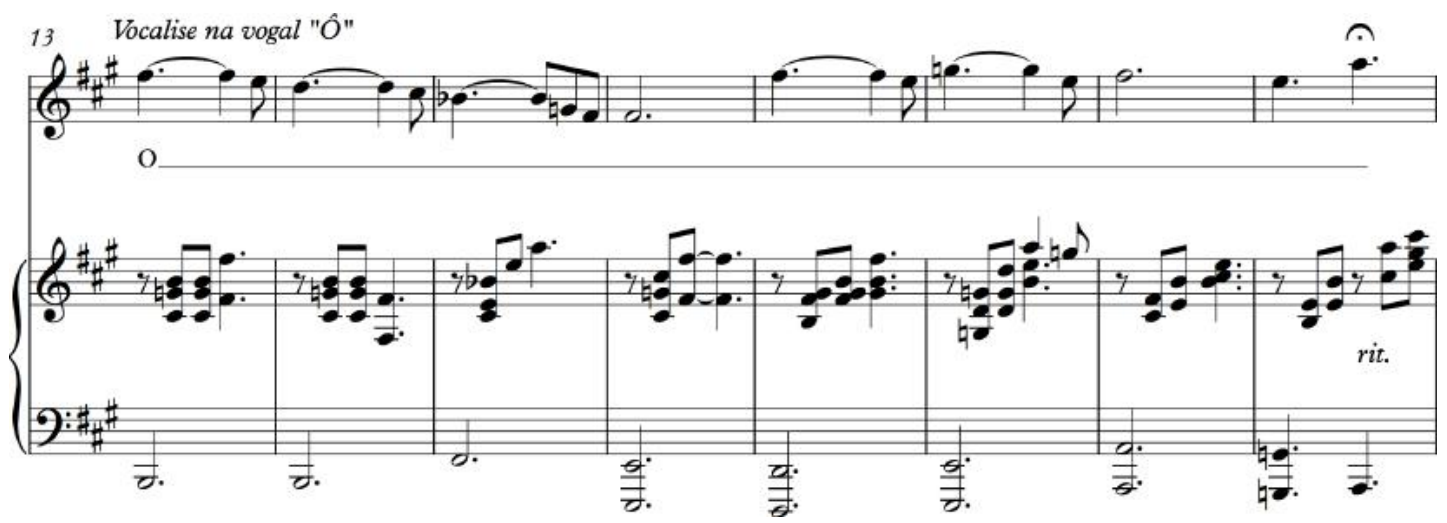

Fonte: MAGRINI (2017, p. 193).

Vocalises estão na essência das canções de ninar, fato que justifica sua presença em Berceuse, em que há uma seção inteira vocalizada. Em $A$ Estrela, somente a última frase da canção é vocalizada (c. 43-45). Nesse caso, a função musical do vocalise em bocca chiusa é adicionar uma camada sonora a mais ao ambiente "nostálgico, como sinos à distância", em pianississimo, criado pela linha do piano. De forma parecida, em As sem-razóes do amor, há também apenas uma frase (c.42-45) vocalizada em bocca chiusa. Por fim, em Água do Coração, há uma seção inteira em que a linha da voz é vocalizada. Sua função é "traduzir”, de maneira mais íntima, os sentimentos que o eu lírico expressou na seção anterior. 


\subsection{Elementos nacionalistas}

A estética nacionalista está presente ao longo de toda a vida de CAPF e, nas cançóes, revela-se principalmente por meio das temáticas utilizadas, da organização da forma de maneira mais tradicional, do uso de material melódico-harmônico tonal e/ou modal (com a presença de funçôes harmônicas claras) e, ainda, da utilização de elementos rítmicos puramente nacionais, muitas vezes, provenientes da cultura afro-brasileira. Uma breve descrição analítica de algumas cançóes pode evidenciar tais características.

Composta em 1952 com uma indicação do compositor de “anterior a Berceuse”, Escuta Moreno foi escrita sobre um texto de autoria do próprio compositor que apresenta um eu lírico feminino declarando de forma "brejeira" seu amor ao "Moreno", por meio de versos regulares em um refrão e outras três estrofes de quatro versos. Do ponto de vista estrutural, trata-se de um Rondó AB-A-C-A-D-A cuja organização está associada à estrutura do texto. Trata-se de uma melodia acompanhada tipicamente tonal, escrita em Ré Maior, contudo, com uma harmonia dissonante em função da utilização de muitos acordes com 6as e 7as.

Também composta em 1952, Berceuse é, como o nome sugere, uma canção de ninar com texto de autoria do próprio compositor. Trata-se de uma melodia apresentada pela linha vocal, acompanhada pelo piano, em uma estrutura formal A-B-A, sendo a Seção A escrita na tonalidade de Réb Maior e a Seção B na tonalidade de Fá Maior. Todo o texto, um pequeno poema de uma única estrofe de quatro versos, é apresentado integralmente na primeira seção. $\mathrm{O}$ eu lírico representa a mãe que canta para o filho dormir: "Dorme, dorme anjinho do céu/ Dorme e sonha no azul/ Brinca com teus lindos sonhos/ Brinca com as ondas do mar”. Na Seção B, a linha do piano realiza uma série de arpejos em sextinas que fazem alusão aos compassos compostos da barcarola e sugerem o movimento de ondas no mar, enquanto a linha vocal realiza um vocalise que faz alusão ao ato de ninar. A Figura 9, a seguir, ilustra a passagem da seção A em Réb Maior para a seção B em Fá Maior e o vocalise escrito para a voz, acompanhado pelos arpejos. 
FERNANDES, Angelo José; MAGRINI, Raíssa Amaral; MIGLIORI, Sarah Victória Santibanez; COELHO, Heitor Basílio. O Ecletismo nas Canções de Câmara para Canto e Piano de Carlos Alberto Pinto Fonseca. Revista Vórtex, Curitiba, v.8, n.2, p. 1-30, 2020.

FIGURA 9 - Passagem da seção A para a seção B de Berceuse, c. 19-22, em que acontece a mudança de tonalidade e de textura no acompanhamento do piano. A linha melódica exemplifica o vocalise que faz alusão ao ato de ninar.

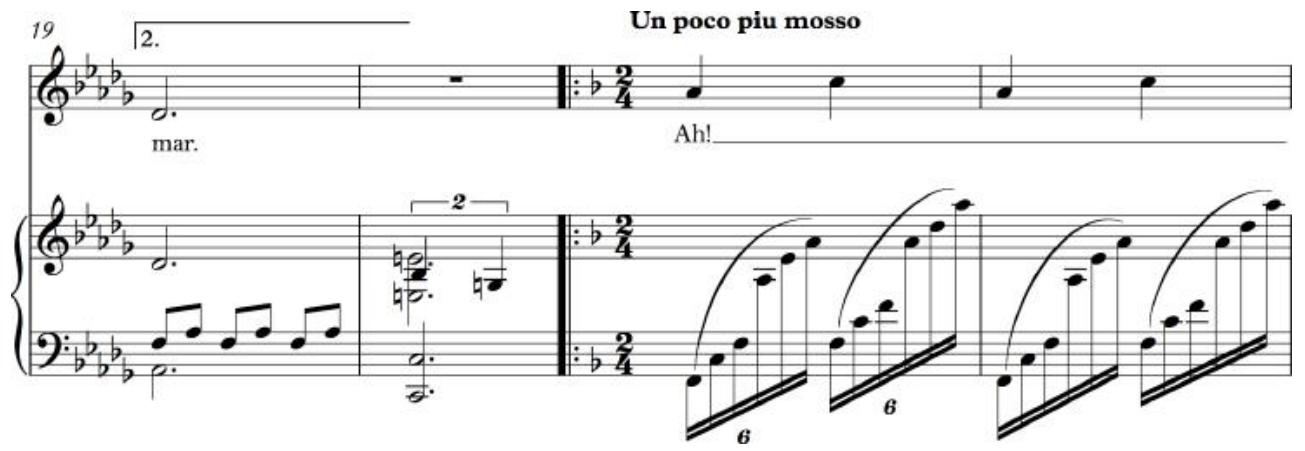

Fonte: MAGRINI (2017, p. 135).

Composta em 08 de março de 1953, sobre um poema de autoria do próprio compositor, Canção da Retirante é uma canção que trata do sofrimento dos retirantes. "Mais especificamente, o texto que narra uma canção de ninar, trata da relação de uma mãe e seu filho, descrevendo a cena em que ela o embala” (MAGRINI, 2017, p. 32). No entendimento da autora, a mãe expressa esperança e otimismo em sua fala, tentando consolar seu filho que tem medo e fome e, por meio disso, consolar a si mesma. Do ponto de vista estrutural, trata-se de uma canção A-B-A, sendo suas seçóes estabelecidas pelos materiais melódico-harmônicos utilizados: modos eólio e dórico de Lá alternados em A e tonalidade de Réb Maior em B.

$\mathrm{Na}$ obra de muitos compositores brasileiros, a temática afro-brasileira está presente de diversas formas, especialmente por meio da rítmica. Oxalá e Ogum de Nagô são canções tipicamente nacionalistas. Foram compostas no mesmo ano (1977) e seus textos são provenientes do livro supracitado 400 Pontos Cantados e Riscados de Umbanda e Candomblé. Tanto em Ogum de Nagô quanto em Oxalá, a temática, o tratamento dado ao ritmo, além da utilização de uma escrita ora tonal, ora modal confirmam seu estilo nacionalista.

Oxalá, escrita para a voz de baixo-barítono, é uma representação musical de uma gira, um culto de Umbanda, na qual há um compilado de quatro pontos cantados para o orixá Oxalá, representado por Jesus Cristo no sincretismo religioso. A música altera trechos recitados com trechos de melodia acompanhada. Em ambos, há uma grande preocupação com o aspecto rítmico. Mesmo nos trechos recitados, o piano atua de forma responsorial, respondendo ao texto cantado com motivos rítmicos que imitam os atabaques conforme mencionado e exemplificado anteriormente. 
FERNANDES, Angelo José; MAGRINI, Raíssa Amaral; MIGLIORI, Sarah Victória Santibanez; COELHO, Heitor Basílio. 0 Ecletismo nas Canções de Câmara para Canto e Piano de Carlos Alberto Pinto Fonseca. Revista Vórtex, Curitiba, v.8, n.2, p. 1-30, 2020.

Ogum de Nagô também apresenta quatro pontos, neste caso, cantados para o orixá Ogum que, no sincretismo religioso, representa São Jorge da Capadócia. "Em entrevista cedida a Santos, CAPF fala que Ogum dança em frente ao seu altar, segurando suas armas, demonstrando quão feliz ele é” (MAGRINI, 2017, p. 68). Em sua análise de Ogum de Nagô, Magrini (2017, p. 69) aponta que a canção se divide em três seções e coda (A-B-C-A-coda), divisão que se estabelece pelas mudanças rítmicas, alternância de centro tonal, textos e marcações de barras duplas. Segundo a autora, o primeiro e o segundo pontos estão na seção A (c. 01-35); o terceiro e o quarto pontos encontram-se na seção B na qual a melodia é apresentada em estilo recitativo acompanhado por acordes de maior duração; a seção C é caracterizada como um momento de invocação; e a coda encerra-se com a saudação “Hei! Saravá!”. Conforme mencionado, a melodia está presente na linha vocal, enquanto o piano, atuando como um ostinato rítmico, imita instrumentos de percussão utilizados nos rituais da cultura africana, com exceção da seção B em que há uma melodia recitada.

O elemento rítmico é de grande importância. Tratado com destaque, "é capaz de criar a atmosfera ritualística da música dos terreiros” (MAGRINI, 2017, p. 73). O tratamento percussivo dado à canção tanto na melodia quanto no acompanhamento ainda inclui acentuações fora do tempo forte e também em sílabas átonas, criando acentos fora da marcação como na Figura 10, a seguir:

\section{FIGURA 10 - Excerto de Ogum de Nagô (c. 19-24) que mostra a inclusão de acentuaçóes fora do tempo forte e em sílabas átonas.}

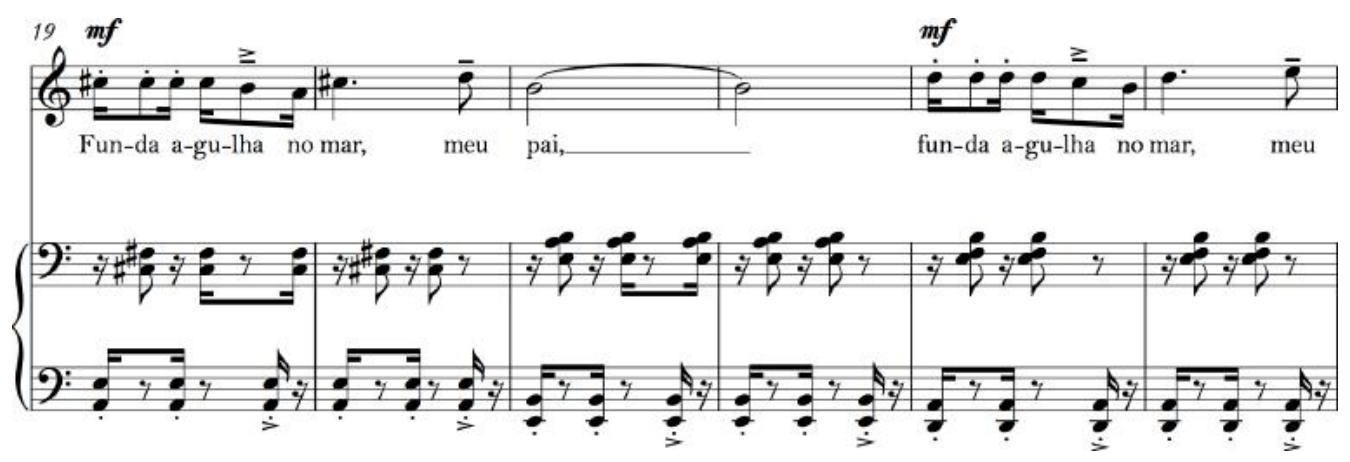

Fonte: MAGRINI (2017, p. 169).

As sem-razóes do amor, composta em 1987 sobre poema de Carlos Drummond de Andrade, trata de uma temática mais abrangente e recorrente em toda a história da canção ocidental: o amor. O poema apresenta um jogo de palavras típico do Modernismo Brasileiro a começar pelo título, além 
FERNANDES, Angelo José; MAGRINI, Raíssa Amaral; MIGLIORI, Sarah Victória Santibanez; COELHO, Heitor Basílio. O Ecletismo nas Canções de Câmara para Canto e Piano de Carlos Alberto Pinto Fonseca. Revista Vórtex, Curitiba, v.8, n.2, p. 1-30, 2020.

de uma estrutura irregular, sendo formado por quatro estrofes: dois sextetos, uma quintilha e um quarteto. Contudo, o que há de nacionalista nesta canção é o tratamento dado ao ritmo por meio do uso constante de síncopas, além da harmonia que, apesar de dissonante, baseia-se na utilização de modos e apresenta funções tonais claras.

\subsection{Elementos impressionistas}

No tocante ao estilo impressionista nas canções de CAPF, Matheus (2010, p. 88) explica que ele se faz presente por meio da escolha de textos simbolistas, do uso de elementos tímbrico-evocativos que se relacionam com o texto, da escala de tons inteiros, de escalas modais, da harmonia estendida, do paralelismo e, ainda, de trechos de indefinição harmônica. Por meio da utilização desses elementos, CAPF demonstrou afinidade com essa estética já nas primeiras composições.

Segundo a autora, nas canções impressionistas a forma foi estabelecida a partir dos poemas, em especial aqueles escritos por R. Tagore, cuja obra é associada ao Simbolismo. Matheus (2010, p. 88) afirma que, nesses poemas, é possível observar “o subjetivismo da estética simbolista e seu transcendentalismo, sugerindo através das palavras e não nomeando objetivamente a realidade”. A autora cita como exemplo o texto de Volta, no qual "o poeta nunca usa a palavra "morte", mas se refere à morte do filho dizendo 'ele foi embora'” (MATHEUS, 2010, p. 89).

De fato, Volta apresenta inúmeros elementos impressionistas. Há vários elementos tímbricoevocativos presentes na escrita do piano que ilustram o significado do texto. Além disso, a utilização da escala de tons inteiros e de escalas modais é uma constante. Na Figura 11, a seguir, é possível observar, logo nos primeiros compassos de Volta, alguns desses elementos impressionistas citados: o primeiro acorde na linha do piano (c. 01) é formado pela escala de tons inteiros, escala que divide a oitava em seis tons inteiros de igual temperamento; na sequência há uma indicação ao pianista de “pianíssimo calmo e distante” que sugere uma ambiência sonora adequada ao texto que diz "a noite estava escura quando ele se foi embora”; a utilização do modo dórico de Lá; e ainda o paralelismo das 5as na mão direita do piano. 
FERNANDES, Angelo José; MAGRINI, Raíssa Amaral; MIGLIORI, Sarah Victória Santibanez; COELHO, Heitor Basílio. O Ecletismo nas Canções de Câmara para Canto e Piano de Carlos Alberto Pinto Fonseca. Revista Vórtex, Curitiba, v.8, n.2, p. 1-30, 2020.

FIGURA 11 - Excerto de Volta (c. 01-04) em que há claramente a utilização de diversos elementos impressionistas: escala de tons inteiros; indicação de pianíssimo calmo e distante; utilização do modo dórico de Lá nos três primeiros compassos; e o paralelismo na mão direita.

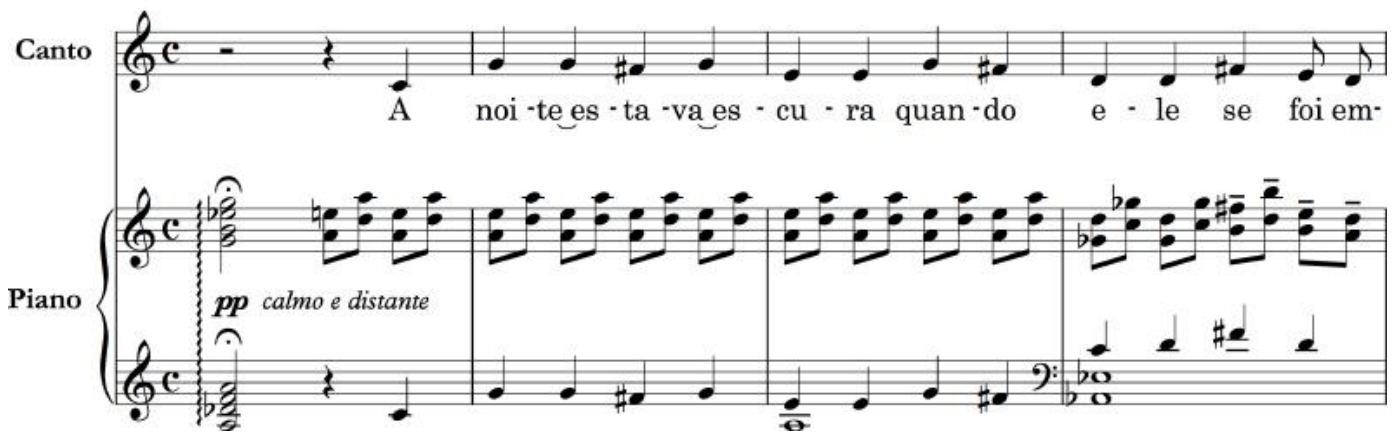

Fonte: MAGRINI (2017, p. 147).

Também escrita sobre um poema de R. Tagore pertencente à coleção Gintanjali, à qual pertencem 193 poemas escritos em híndi, Poema do Gitanjali no 84 é um poema sem rimas, formado por seis versos livres. Segundo Magrini (2017, p. 42), a partir do uso de figuras de linguagem, em especial, metáforas que contribuem para uma atmosfera subjetiva, o poema trata da angústia da separação, sugerindo a morte e um sentimento de aceitação. "A progressão poética é marcada por um sentimento negativo nos cinco primeiros versos, sentimento que se modifica no último na palavra 'cantando', a qual sugere a resignação, indicando que a dor se desfaz e, do coração 'flui, depois, cantando"” (MAGRINI, 2017, p. 42).

Do ponto de vista estrutural, depois de três compassos de introdução, a canção se divide em três seçóes - A, B e C - cada qual contendo dois versos do poema e uma subdivisão em duas frases. Para Magrini (2017, p. 44), apesar dessa divisão, a canção possui uma estrutura semelhante ao chamado through-composed, uma forma associada ao Lied da segunda metade do século XIX, caracterizada pela ausência de repetições formais consistentes. "A unidade e a continuidade ocorrem pela repetição de outros elementos menores, como motivos melódicos e rítmicos”, sendo a forma utilizada para "descrever jornadas emocionais tão diretas e completas que não há necessidade ou mesmo a possibilidade de retorno" (MAGRINI, 2017, p. 44).

Nas seções A e C, a linha vocal tem a nota Mi como centro tonal, seja pela reiteração seja pelo contorno da tríade de Mi menor. Na seção B, há certa indefinição do centro. O material melódicoharmônico utilizado é bastante variado e predominantemente modal. $\mathrm{Na}$ seção $\mathrm{A}$, observamos a presença dos modos dórico e eólio de Mi; na seção B, o compositor utilizou o modo eólio de Sol\# e o 
modo lídio de Dó, além de trechos sem uma referência escalar clara. Em C, o centro tonal volta a Mi, passando pelos modos eólio, frígio e dórico.

Para Magrini (2017, p. 48), um aspecto importante a ser observado nesta canção é o fato de que, em grande parte das seções A e C, a melodia é apresentada na linha vocal dobrada com a parte do piano em ambas as mãos de forma oitavada, ficando o resto da harmonia entre a melodia oitavada. Esse dobramento da melodia pode ser entendido como uma exploração do binômio texto-música na palavra "multiplica". O mesmo procedimento acontece na canção Volta, porém, com menor frequência. A Figura 12 demonstra esse procedimento e, ainda, o uso de acordes paralelos.

FIGURA 12 - Dobramento perfeito da melodia nas duas mãos na linha do piano de forma oitava e na linha vocal (c. 08-11) e paralelismos no piano (c. 12-13), Poema do Gitanjali no 84.

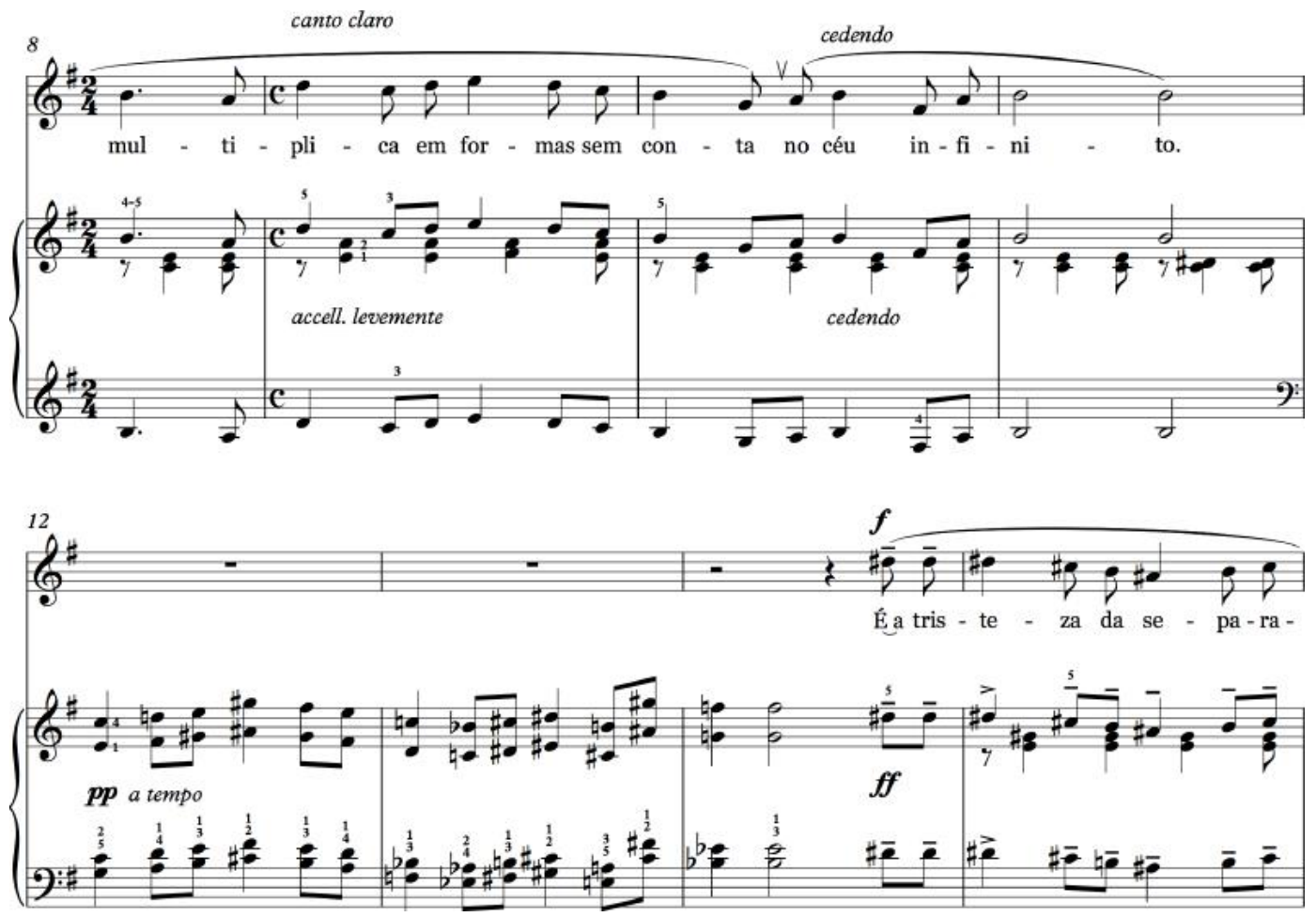

Fonte: MAGRINI (2017, p. 157).

O paralelismo também pode ser encontrado em $A$ Estrela e $O$ Tempo perdido. Na primeira, o paralelismo acontece de forma constante entre as várias vozes do acompanhamento, conforme demonstrado anteriormente. $\mathrm{Na}$ segunda, acontece ocasionalmente. Importante notar que, a utilização de quartas e quintas paralelas na obra de CAPF é uma constante, incluindo suas obras corais. 
Não se pode afirmar que $A$ Estrela, composta sobre poema de Manuel Bandeira, tenha recebido um tratamento impressionista tão elaborado como aquelas canções com textos de R. Tagore. Contudo, está construída no modo eólio de Mi em alternância com o modo frígio; apresenta um movimento paralelo constante; possui indicações de sonoridade muito suaves em pianíssimo; e, nos três últimos compassos, aproxima-se da estética impressionista por meio das indicaçôes de bocca chiusa na linha vocal e de “nostálgico, como sinos à distância” para a realização de 5 ạs paralelas na mão direita do piano, conforme apresentado na Figura 13, a seguir:

FIGURA 13 - Últimos compassos de A Estrela (c. 43-45) em que a linha do canto tem uma indicação de bocca chiusa e a linha do piano apresenta indicaçóes timbrístico-evocativas, além do paralelismo de quintas.

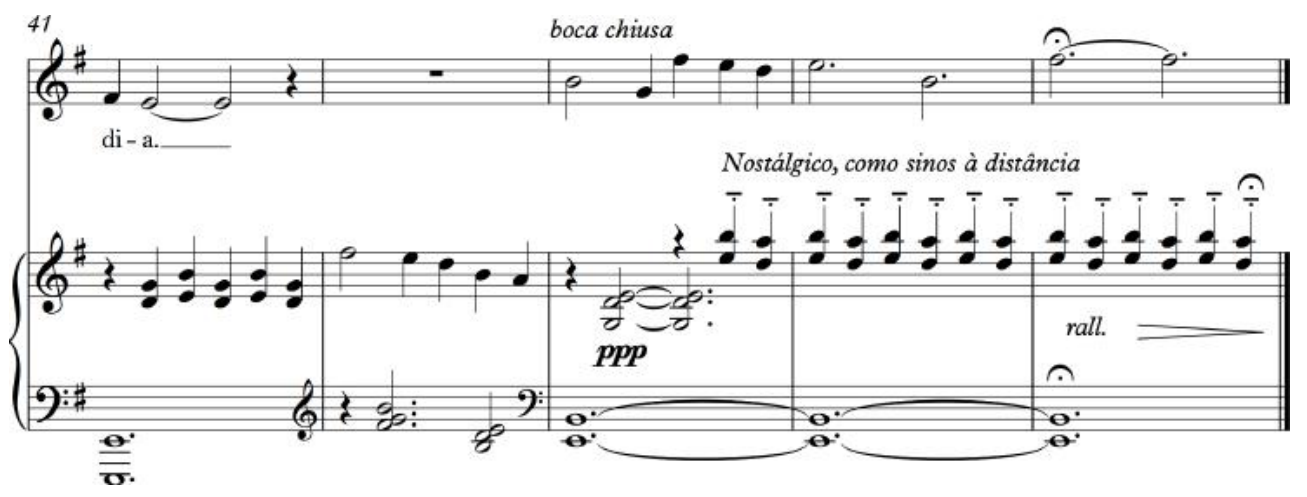

Fonte: MAGRINI (2017, p. 162).

O Tempo Perdido foi escrita sobre um outro texto de R. Tagore que pertence à mesma coleção do Poema de Gitanjali no 84, sendo o poema de no 81. O eu lírico dirige-se a Deus (“Senhor”) em uma espécie de oração por meio da qual ele declara sua "percepção inicial de que o crescimento está ocorrendo em seu 'jardim' de consciência espiritual sempre, secretamente, em silêncio, mesmo quando ele se desespera por seus próprio esforços” (MAGRINI, 2017, p. 98).

A canção é dividida em três seções - A, B e C - estabelecidas pela diferença de seus centros tonais e pela estrutura da linha do piano. Em A, a parte do piano apresenta arpejos; em B, estruturas rítmicas que imitam o mecanismo do relógio; e, em C, intervalos paralelos e elementos apresentados no princípio da canção. "Elementos de ritmo, andamentos, mudanças de fórmulas de compasso e indicações de expressividade também auxiliam na demarcação das seções” (MAGRINI, 2017, p. 99).

Do ponto de vista harmônico é das cançóes que apresentam maior complexidade. Nas seçóes A e C há um centro harmônico em Si, mas o material escalar varia entre os modos eólio e frígio de Si 
FERNANDES, Angelo José; MAGRINI, Raíssa Amaral; MIGLIORI, Sarah Victória Santibanez; COELHO, Heitor Basílio. O Ecletismo nas Canções de Câmara para Canto e Piano de Carlos Alberto Pinto Fonseca. Revista Vórtex, Curitiba, v.8, n.2, p. 1-30, 2020.

na seção A e entre as escalas maior e menor de Si na seção C. A seção B não apresenta uma definição de centro harmônico, sendo baseada em estruturas intervalares paralelas e cromatismos no piano. Para Matheus (2010, p. 83), a atitude do compositor de fugir da previsibilidade harmônica tem o objetivo de criar efeitos "colorísticos".

\subsection{As Cinco cançóes sobre poemas chineses e o atonalismo}

Até aqui, apresentamos um ecletismo nas canções de CAPF que pende para dois lados principalmente: um que valoriza aspectos estéticos, poéticos e musicais do nacionalismo e outro que, claramente, utiliza-se de elementos puramente impressionistas. Contudo, CAPF ainda nos revela um terceiro, por meio do qual ele busca uma aproximação com uma linguagem mais vanguardista, ainda que modesta no caso das cançóes e, por meio da qual, ele se permite o uso de elementos como a atonalidade, politonalidade, clusters, técnicas vocais estendidas, entre outros. Esses elementos, além de outros impressionistas já utilizados, constam na coleção que aqui chamaremos de Cinco cançôes sobre poemas chineses os quais foram traduzidos por Paulo Mendes Campos.

CAPF não especificou um título para esse conjunto de cinco cançóes. $\mathrm{O}$ manuscrito com o qual trabalhamos constitui-se em um rascunho que trazia as cançóes de forma sequencial. Como se trata de cançốes muito curtas, as cinco estavam escritas em apenas três páginas do citado rascunho: $O$ Moinho, de 13 compassos, e Ao Espelho, de seis compassos na primeira página com a marcação I e II antes dos títulos, respectivamente, o que nos permite considerar que são as duas primeiras; Desespero em luz, de 10 compassos, e Fumaça, contendo apenas quatro compassos, na segunda página; por fim, Meu nome, de 12 compassos, na terceira página. A numeração nas duas primeiras, o fato de todas elas aparecerem em sequência no mesmo bloco de rascunho e, ainda, seu pequeno tamanho fazem-nos acreditar que, juntas, formam um conjunto de cançốes a ser executado sequencialmente.

Não há muitos elementos que contribuam para uma maior conexão entre elas. Cada uma dessas pequenas canções possui características e materiais próprios. Além do fato de os textos serem de poemas chineses traduzidos por um mesmo autor, o único elemento que é comum às quatro primeiras é o uso da técnica do Sprechstimme. Em algumas, o compositor alterna alturas escritas com outras a serem recitadas. No caso de Fumaça, ele utilizou somente a recitação. 
O Moinho caracteriza-se pela presença de um ostinato na linha do piano ao longo dos nove primeiros compassos. O material melódico-harmônico é predominantemente modal (Si eólio). Nesta peça, chama-nos a atenção o uso das notas recitadas, conforme mencionado e também de glissandi na linha vocal.

Ao espelho também apresenta um pequeno ostinato na linha do piano. A linha do canto, por sua vez, é praticamente toda recitada com a exceção de uma única sílaba. À primeira vista, a escrita do piano nos sugere o uso do politonalismo, uma vez que a pauta da mão direita não apresenta acidentes e a pauta da mão esquerda apresenta cinco sustenidos. Entretanto, não há centros harmônicos. A intenção do compositor era, provavelmente, a de criar um efeito de cluster resultante dos intervalos de 2 a escritos para serem tocados pelas duas mãos de forma sobreposta: a mão direita nas teclas brancas e a esquerda predominantemente nas teclas pretas, conforme demonstrado na Figura 14:

FIGURA 14 - Excerto de Ao Espelho (c. 01-04) no qual é possível observar as duas armaduras de clave diferentes e a escrita recitada para a linha vocal

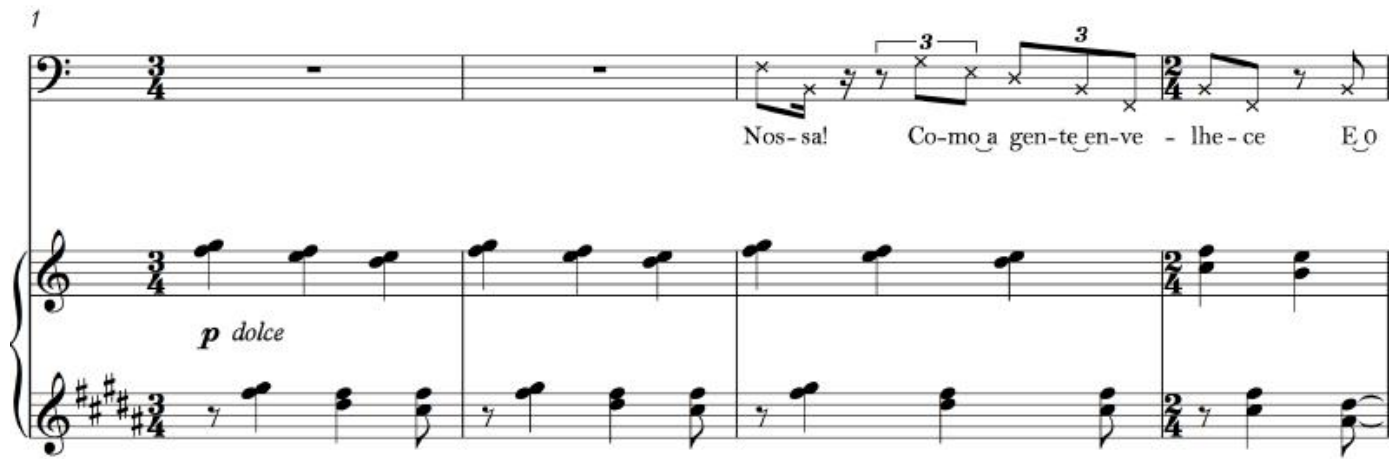

Fonte: MAGRINI (2017, p. 195).

Desespero em luz está escrita em estilo de recitativo, alternando alturas escritas com alturas recitadas. O tratamento é atonal e o compositor utilizou as 12 notas da escala cromática. Assim como nas demais cançôes que utilizam o estilo recitativo, o ritmo da linha vocal é escrito de forma a facilitar a declamação do texto de forma fluente. A preocupação com a prosódia dos textos sempre foi um traço do trabalho de CAPF, seja como compositor, seja como regente.

Por sua vez, Fumaça, a mais curta de todas as canções com apenas quatro compassos, inicia-se com um cluster de quase duas oitavas a ser tocado com o braço direito do pianista e segue com a repetição contínua de um mesmo acorde em pianississimo que sobrepõe as duas mãos (mão esquerda 
em teclas pretas e mão direita em teclas brancas), formando um acorde de quintas e quartas que, por um lado explora a sonoridade do trítono (Fá\#-Dó e Dó\#-Sol) e, por outro, soa como cluster. Essa ambientação sonora faz alusão ao título da canção, como podemos verificar na Figura 15:

FIGURA 15 - Fumaça, canção de quatro compassos que utiliza a recitação na linha do canto, cluster no piano e o mesmo acorde constantemente repetido.

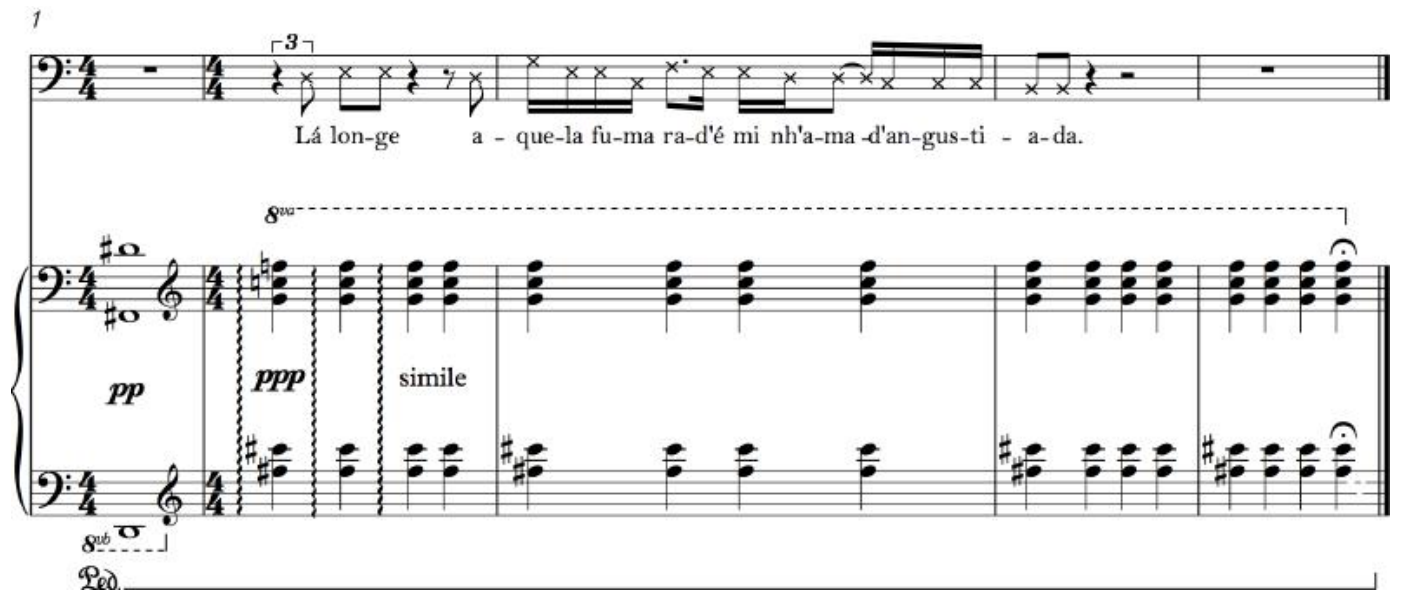

Fonte: MAGRINI (2017, p. 197).

Por fim, Meu nome é a única canção do conjunto de poemas chineses traduzidos para o português que não se vale de recitações. Os materiais melódico-harmônicos utilizados mais predominantemente são: a escala pentatônica construída sobre a nota Lá (c. 01-04), e harmonia quartal paralela.

\section{Considerações finais}

O ecletismo de CAPF comprova-se, no conjunto de suas canções, pela variedade de aspectos apresentados neste trabalho: suas diferentes motivaçốes e inspiraçốes para compor cada uma das cançôes; a escolha dos textos e temáticas; o tratamento dado à voz e ao piano; a utilização de material tonal, modal e atonal; a elaboração rítmica; e outros que atestam a existência de diferentes estéticas, em especial, a nacionalista e a impressionista, além de uma aproximação modesta da linguagem atonal.

Do conjunto de suas 19 canções, seis são adequadas à voz de baixo-barítono - Oxalá e as Cinco cançôes sobre poemas chineses traduzidos por Paulo Mendes Campos - escritas em clave de fá; Escuta 
FERNANDES, Angelo José; MAGRINI, Raíssa Amaral; MIGLIORI, Sarah Victória Santibanez; COELHO, Heitor Basílio. O Ecletismo nas Canções de Câmara para Canto e Piano de Carlos Alberto Pinto Fonseca. Revista Vórtex, Curitiba, v.8, n.2, p. 1-30, 2020.

Moreno, Berceuse e Volta são mais apropriadas para a voz de mezzo-soprano por apresentarem uma tessitura própria desta classificação vocal; por fim, Canção da Retirante, Poema do Gintanjali no 84 , Ogum de Nagô, A Estrela, As sem-razóes do amor, O Tempo perdido, Água do Coração e as duas Ave Marias são para vozes agudas.

As cançôes foram escritas em quatro períodos específicos da vida do compositor - 1952-1955; 1977; 1987-1988; e 1999. Essas composições revelam tendências e inspirações que influenciaram CAPF em sua atividade criativa, das quais destacamos: 1) seu desejo de homenagear determinadas pessoas, sendo a maioria delas cantores com quem conviveu e para quem dedicou nove de suas cançôes; 2) a temática da relação entre mãe e filho expressa em três canções; 3) os elementos simbolistas da poesia de R. Tagore em suas três canções impressionistas; 4) o ambiente religioso afrobrasileiro em duas das canções de 1977; 5) o interesse pela temática oriental, por meio de poemas chineses traduzidos para o português, utilizados em cinco cançóes; e, 6) seu apreço pelo texto da oração católica Ave Maria utilizado em duas canções, além de outras cinco composições para coro.

A partir dessas tendências, observamos o ecletismo presente na escolha dos textos de diferentes origens com os quais trabalhou: poemas de sua própria autoria; poemas simbolistas de R. Tagore; poemas de autores do Modernismo brasileiro; poemas chineses traduzidos; pontos cantados da Umbanda; e, por fim, a oração católica da Ave Maria.

Esses vários textos foram musicalmente tratados de forma diversa, com base, especialmente, nas linguagens nacionalista, impressionista e atonal. Escuta Moreno, Berceuse, Canção da Retirante, As sem-razóes do amor, Oxalá, Ogum de Nagô, e Água do Coração são cançóes tipicamente nacionalistas que utilizam um tratamento harmônico romântico. Volta, Poema do Gitanjali no 84 e O Tempo perdido são composiçôes impressionistas e utilizam inúmeros elementos dessa estética tanto no tratamento harmônico, quanto na escrita do piano. A Estrela tem uma linguagem musical mais híbrida, alternando elementos típicos do nacionalismo com outros puramente impressionistas. $\mathrm{O}$ conjunto das Cinco cançôes sobre poemas chineses difere de toda a produção, apresentando uma linguagem que explora, de forma modesta, elementos de vanguarda, especialmente o idioma atonal e algumas técnicas estendidas. Por fim, as canções sacras intituladas Ave Maria são composições tonais que receberam um tratamento harmônico típico do Romantismo.

Certamente, um olhar mais amplo sobre toda a obra de CAPF, incluindo suas composiçóes 
FERNANDES, Angelo José; MAGRINI, Raíssa Amaral; MIGLIORI, Sarah Victória Santibanez; COELHO, Heitor Basílio. O Ecletismo nas Canções de Câmara para Canto e Piano de Carlos Alberto Pinto Fonseca. Revista Vórtex, Curitiba, v.8, n.2, p. 1-30, 2020.

para outras formações vocais e instrumentais, permitirá o levantamento de uma maior diversidade de elementos que comprovem o ecletismo afirmado pelo compositor, principalmente em suas composiçôes das décadas de 1970 e 1980.

\section{REFERÊNCIAS}

CALAIS, Raquel; CHANTAL, Mauro. Canção da Retirante (1953) de Carlos Alberto Pinto Fonseca: dados históricos, análise e edição de performance da partitura. Diálogos Musicais na PósGraduação: Práticas de Performance. Belo Horizonte, no 5, p. 302-316, 2020.

FERNANDES, Angelo José. De Batuque e Acalanto: uma análise da Missa Afro-Brasileira de Carlos Alberto Pinto Fonseca. Per Musi, Belo Horizonte, no 11, p. 60-72, 2005.

FONSECA, Carlos Alberto Pinto Fonseca. Entrevista concedida a Sérgio Magnani. Belo Horizonte, 1983. Entrevista.

MAGRINI, Raíssa Amaral. As cançôes para voz aguda e piano de Carlos Alberto Pinto Fonseca: análise e interpretação. Campinas, 2017, 197 f. Dissertação (Mestrado em Música). Instituto de Artes, Universidade Estadual de Campinas, Campinas, 2017.

MATHEUS, Rize Lorenze. Elementos impressionistas na obra composicional de Carlos Alberto Pinto Fonseca, Belo Horizonte, 2010. 100 f. Dissertação (Mestrado em Música). Escola de Música, Universidade Federal de Minas Gerais, Belo Horizonte, 2010.

MILLER, Richard. A estrutura do canto: sistema e arte na técnica vocal. São Paulo: É Realizações, 2019.

SANTOS, Mauro Camilo de Chantal. Carlos Alberto Pinto Fonseca: dados biográficos e catálogo de obras. Belo Horizonte, 2001. 80 f. Dissertação (Mestrado em Música). Escola de Música, Universidade Federal de Minas Gerais, Belo Horizonte, 2001.

Sem autor. 400 pontos riscados e cantados na Umbanda e Candomblé. Rio de Janeiro: Eco, 1962.

\section{SOBRE OS AUTORES}

Angelo José Fernandes tem se destacado com grande sucesso por sua dedicação à música vocal e à pedagogia do canto. É docente do Departamento de Música do Instituto de Artes da UNICAMP, sendo responsável por significativa produção artística e acadêmica. Doutor em Música, tem se dedicado ao estudo da técnica vocal nos diversos períodos históricos e sua aplicação na performance atual, além de liderar um grupo de pesquisa que estuda a obra vocal do compositor mineiro Carlos Alberto Pinto Fonseca de quem foi aluno. É diretor artístico do Coro Contemporâneo de Campinas e do Ópera Estúdio UNICAMP. ORCID: https://orcid.org/0000-0001-6117-6702 .E-mail: angelojf@unicamp.br 
FERNANDES, Angelo José; MAGRINI, Raíssa Amaral; MIGLIORI, Sarah Victória Santibanez; COELHO, Heitor Basílio. O Ecletismo nas Canções de Câmara para Canto e Piano de Carlos Alberto Pinto Fonseca. Revista Vórtex, Curitiba, v.8, n.2, p. 1-30, 2020.

Raíssa Amaral Magrini é Bacharela em Música com habilitação em Canto e Cordas Popular pela UNICAMP, tendo sido orientada respectivamente por Angelo José Fernandes e Ulisses Rocha. É Mestre em Práticas Interpretativas tendo defendido dissertação que trata das canções para voz aguda e piano de Carlos Alberto Pinto Fonseca. Atualmente, é doutoranda pela UNICAMP, desenvolvendo uma pesquisa sobre as óperas do compositor Ernst Mahle. Participou de diversos concertos e óperas sob regência de Abel Rocha, Cinthia Aliretti, Vitor Hugo Toro, Silvio Viegas e Roberto Minczuck. ORCID: https://orcid.org/0000-0002-6641-3057.E-mail: raissa.amaral@gmail.com

Sarah Victória Santibanez Migliori é mestranda em Práticas Interpretativas pelo Instituto de Artes da UNICAMP, sendo orientada pelo Prof. Dr. Angelo José Fernandes. É Bacharela em Composição e Regência pela UNESPAR/PR. Foi membro do projeto de pesquisa de música eletroacústica do Prof. Dr. Felipe de Almeida Ribeiro, estudando a interatividade na prática de música eletroacústica. Também foi bolsista pelo CNPq e membra do Núcelo Música Nova. Atua como mezzo-soprano, dando ênfase no repertório clássico e contemporâneo, participando do Ópera Estúdio UNICAMP e do Coro Contemporâneo de Campins. ORCID: https://orcid.org/0000-0003-0239-0324. E-mail: migliorisarah@gmail.com

Heitor Basílio Coelho é Bacharel em Música com habilitação em Canto e mestrando em Práticas Interpretativas pelo Instituto de Artes da UNICAMP, ambos sob orientação do Prof. Dr. Angelo José Fernandes. Tem atuado em diversas montagens operísticas junto ao Ópera Estúdio UNICAMP desde 2014, além de uma vasta experiência coral, ininterrupta, desde 2008. Atualmente, se dedica à pesquisa, estudando as canções de câmara compostas para baixo e barítono de Carlos Alberto Pinto Fonseca. ORCID: https://orcid.org/0000-0002-1514-3405. E-mail: heitorbcoelho@gmail.com 